\title{
25-HC decreases the sensitivity of human gastric cancer cells to 5-fluorouracil and promotes cells invasion via the TLR2/NF- $\kappa B$ signaling pathway
}

\author{
SAISAI WANG ${ }^{1 *}$, YUANYUAN YAO $^{1 *}$, CHUNHUI RAO $^{1}$, GANG ZHENG $^{2}$ and WENBIN CHEN ${ }^{1}$ \\ ${ }^{1}$ Department of Colorectal Surgery, The First Affiliated Hospital, Zhejiang University School of Medicine, \\ Hangzhou, Zhejiang 310003; ${ }^{2}$ Department of Cardiology, The Second Affiliated Hospital, \\ School of Medicine, Zhejiang University, Hangzhou, Zhejiang 310009, P.R. China
}

Received May 11, 2018; Accepted December 10, 2018

DOI: $10.3892 /$ ijo.2019.4684

\begin{abstract}
Hyperlipidemia is associated with metastasis in patients with gastric cancer (GC). 25-Hydroxycholesterol (25-HC) is a type of oxysterol which is synthesized from cholesterol and is involved in a number of processes, including inflammation, immune responses and cancer development. However, the role of $25-\mathrm{HC}$ in gastric cancer remains unknown. In the present study, we demonstrated that 25-HC had no effects on GC cell proliferation and apoptosis, whereas it decreased the sensitivity of GC cells to 5-fluorouracil (5-FU), as demonstrated by the increased cell proliferation and the decreased cell apoptosis. On the other hand, exposure to 2.5-10 $\mu \mathrm{M}$ of 25-HC significantly promoted GC invasion, both in vitro (using AGS and MGC-803 GC cell lines) and in vivo (in an animal model), accompanied by the upregulation of the expression levels of matrix metalloproteinases (MMPs). Further investigations revealed that the promotion of GC invasion was, at least in part due to the activation of Toll-like receptor 2 (TLR2)/nuclear factor (NF)- $\kappa \mathrm{B}$ signaling. Our results demonstrated that $25-\mathrm{HC}$ promoted $\mathrm{GC}$ cells invasion by upregulating TLR2/NF- $\mathrm{B}$-mediated MMP expression. Thus, on the whole, the findings of this study suggest a novel mechanism of hyperlipidemia-induced GC progression.
\end{abstract}

\section{Introduction}

Oxysterols are oxygenated derivatives of cholesterol formed in the human body or ingested in the diet. Oxysterols are associated with various cardiovascular, metabolic, neurodegenerative

Correspondence to: Dr Wenbin Chen, Department of Colorectal Surgery, The First Affiliated Hospital, Zhejiang University School of Medicine, 79 Qingchun Road, Hangzhou, Zhejiang 310003, P.R. China E-mail: wenbinchen@zju.edu.cn

*Contributed equally

Key words: 25-hydroxycholesterol, gastric cancer, 5-fluorouracil, invasion, Toll-like receptor 2 , nuclear factor- $\mathrm{\kappa B}$ and cancerous pathologies (1). Oxysterols have been shown to play pro-cancerous and pro-proliferative roles through the modulation of inflammation or oxysterol-binding proteins in various types of cancer, including breast cancer and lung cancer (2-4). Gastric cancer (GC) is the third leading cause of cancer-related mortality worldwide (5). In China, GC is considered as the second leading cause of cancer-related mortality (6). Dietary patterns, obesity, smoking and chronic infections contribute to the development of GC (7). Hyperlipidemia is associated with lymph node metastasis in patients with GC $(8,9)$. Metformin, a drug used in the treatment of type 2 diabetes for the regulation of glucose and fatty acid metabolism, has been found to inhibit the proliferation and epithelial-mesenchymal transition of AGS GC cells $(10,11)$. In addition, use of statins can reduce the risk of developing GC (12). However, the role of oxysterols in GC and the related mechanisms remain largely unknown.

25-Hydroxycholesterol (25-HC) is a type of oxysterol which is synthesized from cholesterol (13). Johnson et al found that $25-\mathrm{HC}$ was upregulated in serum following the ingestion of a meal rich in oxysterols and following a dietary cholesterol challenge (14). In addition, the levels of $25-\mathrm{HC}$ have been shown to be higher in hypercholesterolemic serum compared to those in normocholesterolemic serum (15). 25-HC has also been found to be involved in the progression of breast and ovarian tumors by activating the estrogen receptor (ER) $\alpha$-mediated signaling pathway (16) and promoting resistance to anti-hormone treatment in ER-positive breast cancer (17). More recently, 25-HC has been reported to promote the migration and invasion of lung adenocarcinoma cells (18). Increased cholesterol levels are often associated with obesity (19), which has been found to be a risk factor for the development of GC (20). Thus, we hypothesized that 25-HC may play a role in the development of GC. To date, at least to the best of our knowledge, the mechanisms of oxysterol-induced GC progression remain largely unknown.

Therefore, in the present study, we evaluated the role of $25-\mathrm{HC}$ in GC both in vitro and in vivo. Our data revealed that $25-\mathrm{HC}$ had no effects on GC cell proliferation and apoptosis, whereas it decreased the sensitivity of the cells to 5-fluorouracil (5-FU). Moreover, 25-HC promoted GC cell invasion and the underlying 
mechanisms partly involved the upregulation of Toll-like receptor 2 (TLR2)/nuclear factor (NF)-кB signaling-dependent matrix metalloproteinase (MMP) expression.

\section{Materials and methods}

Cells and reagents. The human GC cell lines, AGS and MGC-803, were obtained from the Cell Bank of the Type Culture Collection of Chinese Academy of Sciences (Shanghai, China). The AGS cells were cultured in F-12K medium and the MGC-803 cells were cultured in RPMI-1640 medium complemented with $10 \%$ heat-inactivated fetal bovine serum (FBS) and maintained at $37^{\circ} \mathrm{C}$ with $5 \% \mathrm{CO}_{2}$ in a humidified tissue culture incubator. All cell culture reagents were purchased from Invitrogen (Shanghai, China).

25-HC was purchased from Sigma-Aldrich (Shanghai, China) and dissolved in ethanol as a stock solution. Rabbit anti-MMP1 polyclonal antibody (pAb, \#10371-2-AP), rabbit anti-MMP2 pAb (\#10373-2-AP), rabbit anti-MMP3 pAb (\#17873-1-AP), rabbit anti-MMP9 pAb (\#10375-2-AP) and rabbit anti-MMP13 pAb (\#18165-1-AP) were obtained from Proteintech (Wuhan, China). Rabbit anti-Bcl-2 monoclonal antibody (mAb, \#4223), rabbit anti-Bax mAb (\#5023), rabbit anti-phospho-PI3K p85/ p55 mAb (\#4228), rabbit anti-PI3K p85 mAb (\#4292), rabbit anti-phospho-AKT mAb (\#4060), rabbit anti-AKT mAb (\#4691), rabbit anti-phospho-signal transducer and activator of transcription 3 (STAT3) mAb (\#9145), rabbit anti-STAT3 mAb (\#4904), rabbit anti-phospho-p38 mAb (\#9211), rabbit anti-p38 mAb (\#9212), rabbit anti-phospho-extracellular signal-regulated protein kinase (Erk)1/2 mAb (\#4370), rabbit anti-Erk1/2 mAb (\#4695), rabbit anti-phospho-stress-activated protein kinase (SAPK)/c-Jun NH2-terminal kinase (JNK) mAb (\#4668), rabbit anti-SAPK/JNK pAb (\#9252), rabbit anti-phospho-NF-кB p65 $\mathrm{mAb}$ (\#3039), rabbit anti-NF- $\mathrm{kB}$ p65 mAb (\#8242) and rabbit anti- $\beta$-actin $\mathrm{mAb}$ (\#8457) were purchased from Cell Signaling Technologies (CST; Danvers, MA, USA). Rabbit anti-TLR2 pAb (\#DF7002), rabbit anti-TLR3 pAb (\#DF6415), rabbit anti-TLR4 pAb (\#AF7017), rabbit anti-TLR9 pAb (\#DF2970) were purchased from Affinity Biosciences (Jiangsu, China). HRP-linked anti-rabbit IgG Ab (\#70-GAR007) was obtained from MultiSciences (Lianke) Biotech Co., Ltd. (Hangzhou, China). FITC anti-human CD44 antibody (\#103021) was purchased from BioLegend (San Diego, CA, USA).

Measurement of cell viability. Cell viability was detected by Cell Counting kit- 8 assay (Beyotime, Jiangsu, China) according to the manufacturer's instructions. The cells were seeded in 96-well plate at a density of $1 \times 10^{3}$ cells/well and allowed to grow for $24 \mathrm{~h}$ before the medium was replaced with either ethanol as the vehicle or various concentrations of $25-\mathrm{HC}(2.5$, 5 and $10 \mu \mathrm{M})$ in a total volume of $100 \mu 1$. Following culture for 24, 48 and $72 \mathrm{~h}, 10 \mu \mathrm{l}$ of CCK-8 solution reagent were added to each well and cultured for a further $1 \mathrm{~h}$. The absorbance at $450 \mathrm{~nm}$ was measured using an ultra-microplate reader (Emax, Molecular Devices, CA, USA).

To investigate the role of $25-\mathrm{HC}$ in the chemosensitivity to 5-FU, the AGS or MGC-803 cells seeded in 96-well plates were treated with various concentrations of $25-\mathrm{HC}$ with or with 5 -FU $(5 \mu \mathrm{M})$ for 24 or $48 \mathrm{~h}$ before cell viability was determined by CCK- 8 assay as described above.
Annexin V cell apoptosis assay. Cells in a 6-well plate were treated with various concentrations of $25-\mathrm{HC}$ with or without 5-FU ( $5 \mathrm{uM})$ for $48 \mathrm{~h}$ before the cells were trypsinized, washed with ice-cold PBS and resuspended. Cell apoptosis was determined with the Annexin V apoptosis kit (Lianke Biotech, Co., Ltd.) according to the manufacturer's instructions. The stained cells were then analyzed by flow cytometry (BD FACScan; BD Biosciences, San Jose, CA, USA).

Western blot analysis. Cells or tissues from the lungs of mice were washed with ice-cold PBS 3 times and lysed with RIPA buffer (CST, Danvers, MA) containing $1 \mathrm{mM}$ phenylmethylsulfonyl fluoride (PMSF) (CST) and protease inhibitor cocktail. Equal amounts of proteins were separated by $10 \%$ SDS-polyacrylamide gel electrophoresis and blotted onto PVDF membranes. The membranes were blocked with PBS containing $5 \%$ non-fat milk for $1.5 \mathrm{~h}$ at room temperature, followed by incubation with primary antibodies against MMP1, MMP2, MMP3, MMP9, MMP13, Bcl-2, Bax, p-PI3K p85/p55, PI3K p85, p-AKT, AKT p-STAT3, STAT3, p-p38, p38, p-Erk1/2, Erk1/2, p-SAPK/JNK, SAPK/JNK p-NF-kB p65, NF-кB p65, TLR2, TLR3, TLR4, TLR9 and $\beta$-actin (all diluted 1:1,000) overnight at $4^{\circ} \mathrm{C}$. Following incubation with the HRP-linked goat anti-rabbit secondary antibody (dilution 1:5,000) for $1 \mathrm{~h}$ at room temperature, immunoreactive proteins were detected with FluorChem E System (ProteinSimple, Santa Clara, CA, USA).

For the inhibition assay, cells in 6-well plates were pre-treated with the NF- $\kappa B$-specific inhibitor, Bay 11-7082 at $2 \mu \mathrm{g} / \mathrm{ml}$ (Beyotime Institute of Biotechnology, Shanghai, China) for $1 \mathrm{~h}$ and medium were replaced with the complete medium supplemented with $25-\mathrm{HC}$.

Animal experiments. All the experiments using animals were approved by the Animal Care and Use Committee of Zhejiang University. Five to six-week-old female BALB/c nude mice (90 in total), weighing between 18-20 g were purchased from Shanghai Laboratory Animal Company (SLAC; Shanghai, China) and maintained in the animal facility at Zhejiang University. Mice were provided with water and food (SLAC) ad libitum and kept under standard conditions (temperature $24 \pm 2^{\circ} \mathrm{C}$, humidity, $50-70 \%, 12$-h light/dark cycle).

For tumor growth assays, $5 \times 10^{6}$ AGS cells were subcutaneously injected into the right flanks of the nude mice. When the volumes of the xenograft tumors reached an average of $100 \mathrm{~mm}^{3}$, the mice were randomly divided into 4 groups as follows: The PBS and 25-HC groups (with 5 mice in each group), and the PBS + 5-FU and 25-HC + 5-FU groups (with 10 mice in each group). The mice in the PBS $+5-\mathrm{FU}$ and $25-\mathrm{HC}+5-\mathrm{FU}$ groups received 5-FU or/and 25-HC via intraperitoneal injection with $5-\mathrm{FU}(25 \mathrm{mg} / \mathrm{kg})$ or $/$ and $25-\mathrm{HC}(10 \mathrm{mg} / \mathrm{kg})$ every 3 days for 3 weeks. After 3 weeks, the mice were sacrificed, and the tumors were harvested and weighed, and embedded in paraffin for use in further analyses. Tumor volume was calculated using the following formulae: $V=1 / 2 x$ (length $x$ width ${ }^{2}$ ). This experiment was repeated under the same setting 3 times (once with 10 mice in total, and another 2 times with 20 mice each time).

For lung metastasis assay, the mice were injected with $1 \times 10^{6}$ of AGS cells through the tail vein and randomly divided into 2 groups (PBS and 25-HC group) with 8 mice in each group. Mice in the 25-HC group were intraperitoneally injected with 
Table I. Sequences of primers used for RT-qPCR.

\begin{tabular}{lll}
\hline Gene & \multicolumn{1}{c}{ Forward } & \multicolumn{1}{c}{ Reverse } \\
\hline$\beta$-actin & GTATCCTGACCCTGAAGTACC & TGAAGGTCTCAAACATGATCT \\
TLR2 & CTCTTCAGCAAACGCTGTTCT & GGCGTCTCCCTCTATTGTATTG \\
TLR3 & GTGAGATACAACGTAGCTGACTG & TCCTGCATCCAAGATAGCAAGT \\
TLR4 & GCCTTTCAGGGAATTAAGCTCC & GATCAACCGATGGACGTGTAAA \\
TLR9 & ACAACTCTGACTTCGTCCACC & TCTGGGCTCAATGGTCATGTG \\
\hline
\end{tabular}

$25-\mathrm{HC}(10 \mathrm{mg} / \mathrm{kg})$ every 3 days for 3 weeks. This experiment was repeated twice (with 20 mice being prepared each time). After 3 weeks, the mice were sacrificed, and the lungs were removed and weighted. The lung metastatic tumors on the surface were calculated and H\&E staining was performed on the lung tissues or part of the lung tissues were extracted for protein extraction for use in western blot analysis. H\&E staining was performed by Google Biotechnology Co., Ltd. (Wuhan, China).

Cell cycle assay. The cell cycle was analyzed with the Cell Cycle Staining kit (Lianke Biotech, Co., Ltd.) according to the manufacturer's instructions. Cells in a 6-well plate were treated with various concentrations of $25-\mathrm{HC}$ with or without 5 -FU $(5 \mu \mathrm{M})$ for $48 \mathrm{~h}$ before the cells were trypsinized, washed with ice-cold PBS and fixed with $75 \%$ ethanol at $-20^{\circ} \mathrm{C}$ overnight. The cells were then stained with PI solution for $30 \mathrm{~min}$ in the dark. Cell cycles were analyzed by flow cytometry (BD FACScan; BD Biosciences).

Wound healing assay. The AGS cells were seeded and allowed to grow to $80 \%$ confluence in complete medium before cells were wounded by a $200-\mu \mathrm{l}$ pipette. The cells were then washed with PBS twice and replenished with fresh culture medium with 5\% FBS containing the indicated concentrations of 25-HC. Images of the wound morphology were acquired under a light microscope (CKX41; Olympus, Shanghai, China).

Cell invasion assay. Cell invasion assay was carried out using 24-well cell culture chambers with an $8-\mu \mathrm{m}$ pore filter (Corning Costar Corp., Cambridge, MA, USA). Before the cells were seeded, the upper surfaces of the membranes were coated with $50 \mu \mathrm{l}$ Matrigel (BD Biosciences) for $6 \mathrm{~h}$ at $37^{\circ} \mathrm{C}$. The cells were then seeded at a density of $1 \times 10^{5}$ cells/well in $100 \mu \mathrm{l}$ serum-free F-12K medium added onto the top chamber of each Transwell with various concentrations of $25-\mathrm{HC}$. The cells were allowed to invade for $36 \mathrm{~h}$ at $37^{\circ} \mathrm{C}$. After removing the cells that had remained in the upper side of the membrane with a cotton swab, cells in the lower side of the membrane were fixed with ice-cold methanol, stained with crystal violet (Hushi, Shanghai, China) in 20\% ethanol overnight and then counted in 5 pre-determined fields under a light microscope (CKX41; Olympus).

For the inhibition assay, cells in the upper chamber were pre-treated with NF- $\kappa$ B inhibitor Bay $11-7082$ at $2 \mu \mathrm{g} / \mathrm{ml}$ (Beyotime) for $1 \mathrm{~h}$ and the medium was replaced with FBS-free medium supplemented with $25-\mathrm{HC}$ or not.

Reverse transcriptase-quantitative polymerase chain reaction (RT- $q P C R)$. The AGS cells were exposed to $25-\mathrm{HC}$ at various concentrations for $24 \mathrm{~h}$ and total RNA was extracted using the Ultrapure RNA kit (Cwbiotech, Beijing, China). Reverse transcriptase PCR was performed with the HiFiScript cDNA Synthesis kit (Cwbiotech). Subsequently, quantitative PCR (qPCR) was performed using the iTaq Universal SYBR-Green Supermix on a CFX96 Touch Real-Time PCR Detection System (both from Bio-Rad, Hercules, CA, USA). The primer sequences used are listed in Table I. The results of qPCR were analyzed with the relative quantification Delta delta CT $\left(2^{-\Delta \Delta C q}\right)$ strategy (21). The calculated threshold cycle was normalized to the value of internal $\beta$-actin amplified from the same cDNA and the fold-change was calculated as referenced to control.

Luciferase reporter assay. The AGS cells were seeded in 96-well plate at a density $1 \times 10^{4}$ per well 1 day prior to transfection. The cells were transiently transfected with NF- $\mathrm{\kappa B}$ luciferase reporter plasmid with Lipofectamine 2000 (Invitrogen/Thermo Fisher Scientific, Waltham, MA, USA) following the manufacturer's instructions. At $24 \mathrm{~h}$ post-transfection, the cells were stimulated with the indicated concentrations of 25-HC. After $24 \mathrm{~h}$, the cells were collected, and the luciferase activities were determined by using the Bright-Glo luciferase assay system (Promega Corp., Madison, WI, USA).

siRNA transfection. siRNA targeting human TLR2 (5'-GGA GUCUCUGUCAUGUGAUdTdT-3') and scramble siRNA (siNC) (5'-UUCUCCGAACGUGUCACGUTTdTdT-3') were purchased from GenePharma Technologies (Shanghai, China). The AGS cells were transfected with the siRNAs using Lipofectamine 2000 (Invitrogen/Thermo Fisher Scientific) following the manufacturer's instructions. Following transfection for $24 \mathrm{~h}$, the cells were prepared for use in further experiments.

Flow cytometry for the determination of CD44 expression. The AGS cells in 6-well plate were treated with various concentrations of $25-\mathrm{HC}$ for $48 \mathrm{~h}$ before the cells were trypsinized, washed with ice-cold PBS, resuspended and counted prior to staining for flow cytometric analysis. In $100 \mu 1$ of buffer, $1 \times 10^{6}$ cells were incubated with the anti-CD44-FITC on ice for $30 \mathrm{~min}$. The cells were then washed with buffer and fixed in $1 \%$ paraformaldehyde for $30 \mathrm{~min}$ on ice. Following fixation, the cells were washed, and the fluorescence intensity was assessed by flow cytometry (BD FACScan; BD Biosciences, San Jose, CA, USA).

Statistical analysis. Data are presented as the means \pm SEM. Statistical significance was determined by a Student's t-test or one-way analysis of variance (ANOVA) followed by Dunnett's 
test or Tukey's test. A P-value $<0.05$ was considered to indicate a statistically significant difference.

\section{Results}

25-HC has no effects on GC cell proliferation and apoptosis in vitro. To explore the biological effects of $25-\mathrm{HC}$ on GC cell proliferation, we first evaluated cell proliferation by CCK- 8 assay. The AGS or MGC-803 cells were exposed to the indicated concentrations of $25-\mathrm{HC}$ for 24,48 and 72 h. As shown in Fig. 1A, 25-HC had no effect on GC cell proliferation. The regulation of fatty acid metabolism can decrease GC cell viability and induce cell apoptosis (10). Thus, in this study, we also detected cell apoptosis by flow cytometry, as well as the expression levels of the apoptotic regulators, Bcl-2 and Bax by western blot analysis. Consistent with the results of cell proliferation assay, 25-HC had no marked effects on cell apoptosis (Fig. 1B) or on the expression levels of Bcl-2 and Bax (Fig. 1C). These results demonstrate that $25-\mathrm{HC}(2.5-10 \mu \mathrm{M})$ has no effects on GC cell proliferation and apoptosis.

25-HC decreases the sensitivity of GC cells to 5-FU. To examine the effects of $25-\mathrm{HC}$ on the chemoresistance of GC cells, the AGS and MGC-803 cells were treated with 25-HC with or without 5-FU and cell proliferation were evaluated. As shown in Fig. 2A, although $25-\mathrm{HC}$ had no effect on cell proliferation directly, it decreased the sensitivity of the GC cells to 5-FU with a significant increase in absorbance at $450 \mathrm{~nm}$ compared to 5-FU stimulation alone in a dose-dependent manner. In mouse tumor xenograft experiments, the tumor volume and weight in the $25-\mathrm{HC}$ group exhibited no marked difference compared with the PBS group. However, following $5-\mathrm{FU}$ treatment, tumor growth was enhanced by $25-\mathrm{HC}$, as evidenced by the greater tumor volume and increased tumor weight compared to the PBS + 5-FU group (Fig. 2B). Thus, these results indicate that $25-\mathrm{HC}$ decreases the sensitivity to 5-FU in AGS cells both in vitro and in vivo.

25-HC decreases the pro-apoptotic effects of 5-FU on $G C$ cells. We then investigated the effects of $25-\mathrm{HC}$ on cell apoptosis induced by 5 -FU. The cells were treated with $25-\mathrm{HC}$ with or without $5 \mu \mathrm{M} 5$-FU for $48 \mathrm{~h}$ and the apoptotic cells were determined by Annexin V/PI staining. As shown in Fig. 3A, upon 5-FU treatment, the apoptotic rates of the AGS cells $(16.7 \pm 0.75 \%)$ decreased significantly following $25-\mathrm{HC}$ stimulation $(12.9 \pm 0.19 \%$ at $2.5 \mu \mathrm{M}$ and $10.4 \pm 0.37 \%$ at $10 \mu \mathrm{M}$; $\mathrm{P}<0.05)$. Similar results were obtained with the MGC-803 cells. Moreover, the increased expression of $\mathrm{Bcl}-2$ and the decreased expression of Bax in the AGS cells following treatment with 5-FU were detected (Fig. 3B). Overall, these results indicate that $25-\mathrm{HC}$ decreases the pro-apoptotic effects of 5-FU on GC cells.

25-HC arrests the cell cycle of the GC cells at the S-phase following 5-FU treatment. The cell cycle distribution of the 25-HC-exposed GC cells treated with or without 5-FU was analyzed and quantified by flow cytometry. As shown in Fig. 4, 25-HC treatment alone had minimal effects on cell cycle arrest in the AGS and MGC-803 cells, which was consistent with the results of proliferation assay. However, an increase in the population of cells in the S-phase following 5-FU treatment was observed in a dose-dependent manner, ranging from $12.62 \pm 0.8 \%$ to $20.1 \pm 0.4 \%$ to $32.24 \pm 1.9 \%$ in the AGS cells and $21.53 \pm 0.7 \%$ to $23.33 \pm 2.0 \%$ to $27.67 \pm 0.9 \%$ in the MGC -803 cells $(25-\mathrm{HC}$ at $0,2.5$ and $10 \mu \mathrm{M}$, respectively, $\mathrm{P}<0.05)$. Additionally, the numbers of cells in the G0/G1 phase were significantly decreased with the increasing concentrations of 25-HC $(\mathrm{P}<0.05)$.

25-HC promotes GC cell migration and invasion in vitro. We then investigated the effects of $25-\mathrm{HC}$ on GC cell migration and invasion in vitro. First, we performed a Transwell invasion assay. Compared to the control group, 25-HC treatment significantly enhanced the AGS cell and MGC-803 invasive ability $(\mathrm{P}<0.05$; Fig. $5 \mathrm{~A})$. A wound healing assay was then carried out on the AGS cells. The results revealed that $25-\mathrm{HC}$ treatment induced the more rapid closing of the scratch wounds in the AGS cells (Fig. 5B), indicating that 25-HC efficiently promoted the motility of the AGS cells.

Metastasis involves tumor cell adhesion to the extracellular matrix (ECM), proteolytic cleavage or destruction of the ECM, and leads to cell migration through the resultant defect $(22,23)$. MMPs are a group of enzymes that can degrade proteins in the ECM by the endopeptidase activity (24). Thus, in this study, we detected the MMP1, MMP2, MMP3, MMP9 and MMP13 expression levels which have been found to be overexpressed in human GC $(25,26)$. As shown in Fig. 5C, 25-HC increased the expression levels of the detected MMPs in a dose- and time-dependent manner.

25-HC promotes the distant lung metastasis of AGS cells in vivo. To determine whether the promoting effects of $25-\mathrm{HC}$ on GC cell invasion in vitro can be reproduced in vivo, the AGS cells were injected into the tail veins of BALB/c nude mice pre-treated with PBS or 25-HC. As shown in Fig. 6A, following 25-HC treatment, the number of metastatic nodules in lungs was significantly increased and the lung weight was also increased $(\mathrm{P}<0.01)$. In addition, the protein expression levels of MMP1, MMP2, MMP3 and MMP9 in the lung tissues were determined by western blot analysis. As shown in Fig. 6B, the expression levels of all the detected MMPs were much higher in the mice treated with 25-HC. Taken together, these data demonstrate that $25-\mathrm{HC}$ strongly promotes the in vivo lung metastatic potential of GC cells.

25-HC regulates multiple signaling pathways. To identify the 25-HC-associated signaling pathways, western blot analysis was performed. The mitogen-activated protein kinase (MAPKs, including JNK, Erk and p38), NF-кB, PI3K/ AKT and STAT3 signaling pathways have been associated with GC cell migration and invasion $(27,28)$. The suppression of these signaling pathways can inhibit the migration and invasion of AGS cells, and the activation of these pathways promotes cell invasion and metastasis (29-31). The results of this study demonstrated that 25-HC upregulated the phosphorylation of $\mathrm{NF}-\kappa \mathrm{B}$ p65 in a dose- and time-dependent manner, while it decreased the phosphorylation levels of all the other proteins detected (Fig. 7A). We also assessed NF- $\mathrm{BB}$ activation using 
A

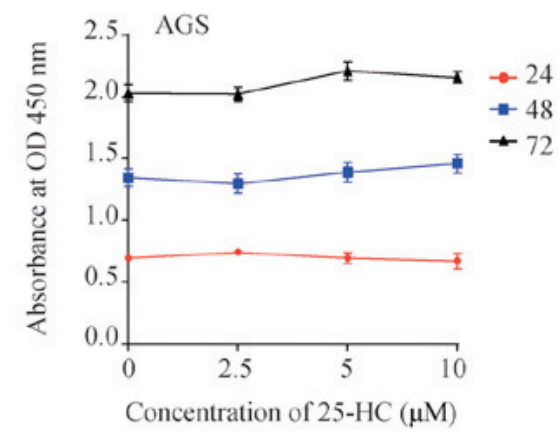

B

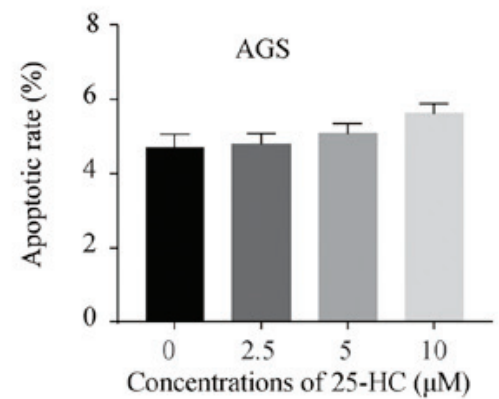

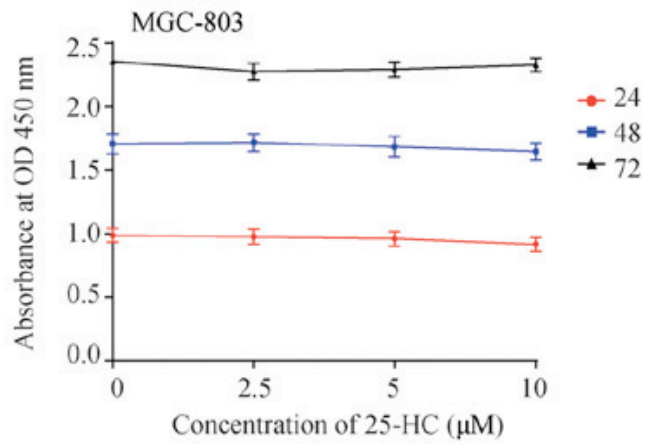

MGC-803

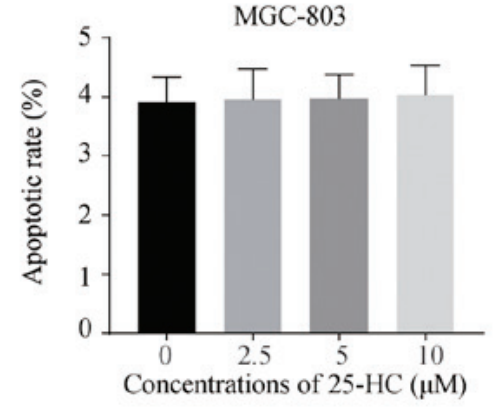

$25-\mathrm{HC}$
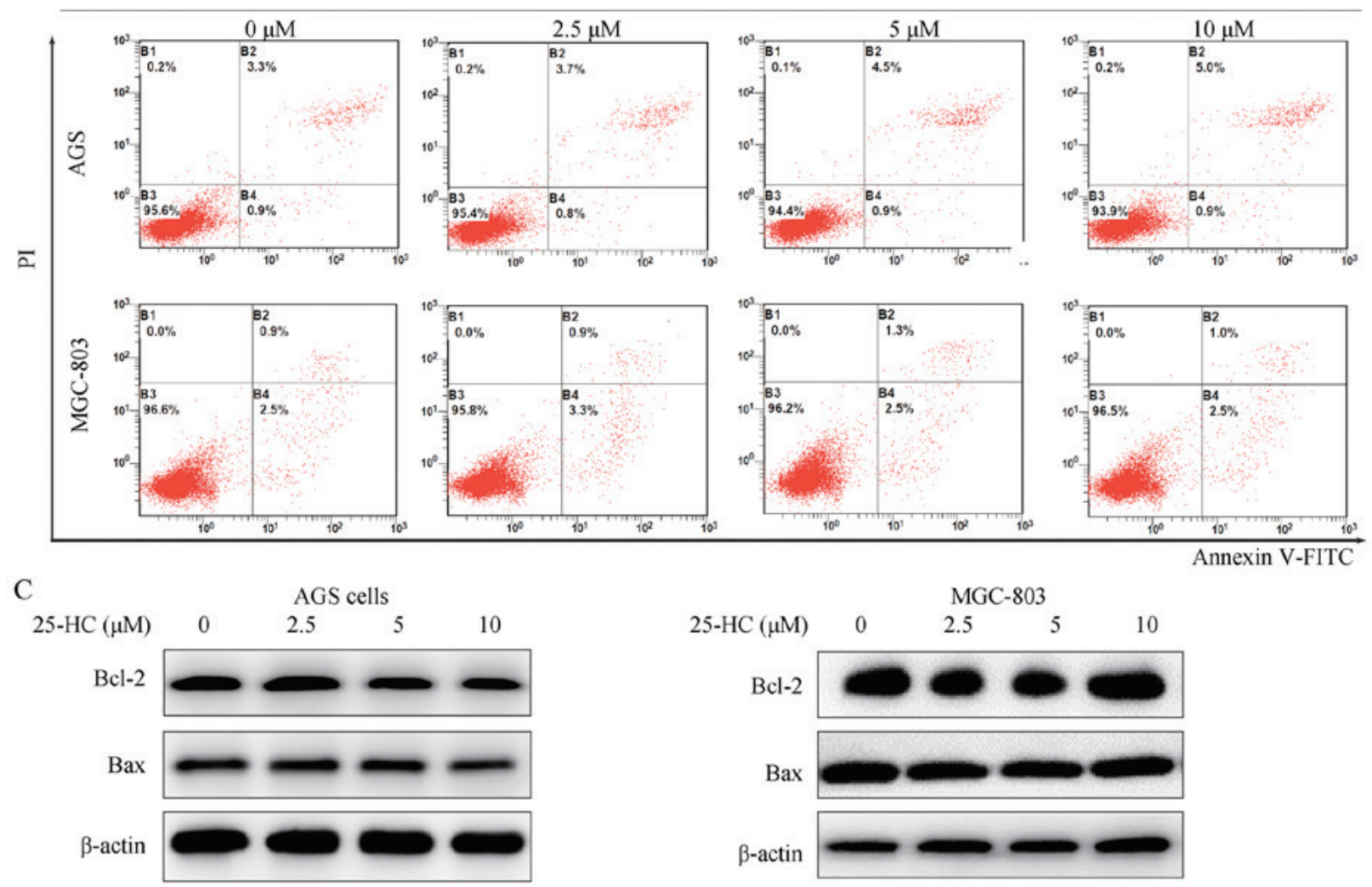

Figure 1.25-HC has no effects on GC cell proliferation and apoptosis in vitro. (A) AGS cells or MGC- 803 cells were treated with the indicated concentrations of $25-\mathrm{HC}$ for 24,48 or $72 \mathrm{~h}$ followed by CCK- 8 assay. The absorbance at $450 \mathrm{~nm}$ was measured. (B) AGS cells or MGC-803 cells were treated with $25-\mathrm{HC}$ at the indicated concentrations for $48 \mathrm{~h}$ and apoptosis was examined by FITC-Annexin V/PI staining. The fluorescence intensity of FITC-Annexin V was plotted on the X-axis, and PI was plotted on the y-axis. The statistical analysis of apoptotic GC cells (FITC ${ }^{+}$) were calculated. (C) Cells were treated with 25-HC for $48 \mathrm{~h}$ and total cellular proteins were extracted for western blot analysis to detect the Bcl-2 and Bax expression levels. Results were obtained from 3 independent experiments and are expressed as the means \pm SEM. 25-HC, 25-hydroxycholesterol; GC, gastric cancer.

a luciferase reporter assay. Following exposure to increasing concentrations of $25-\mathrm{HC}, \mathrm{NF}-\mathrm{kB}$ activity was significantly induced in a dose-dependent manner (Fig. 7B). These results indicate that NF- $\mathrm{KB}$ may be responsible for the induction of the migration and invasion of AGS cells.
25-HC promotes AGS cell invasion and MMP expression levels through the upregulation of the $N F-\kappa B$ pathway. Subsequently, the AGS cells were treated with the NF- $\kappa B$ specific inhibitor, Bay 11-7082, prior to 25-HC treatment, and the invasive ability and MMP expression levels were analyzed. 
A

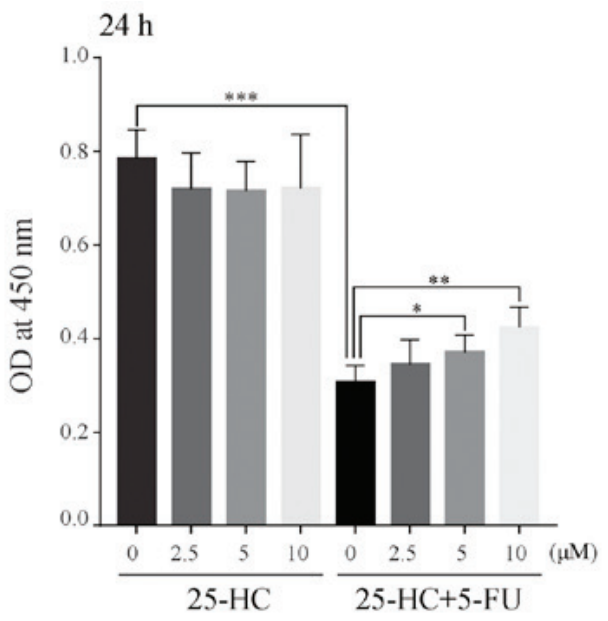

$24 \mathrm{~h}$

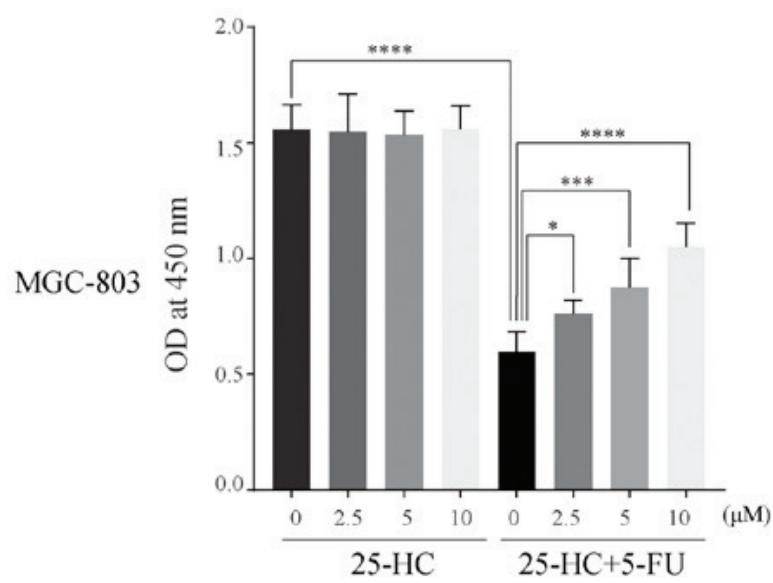

B

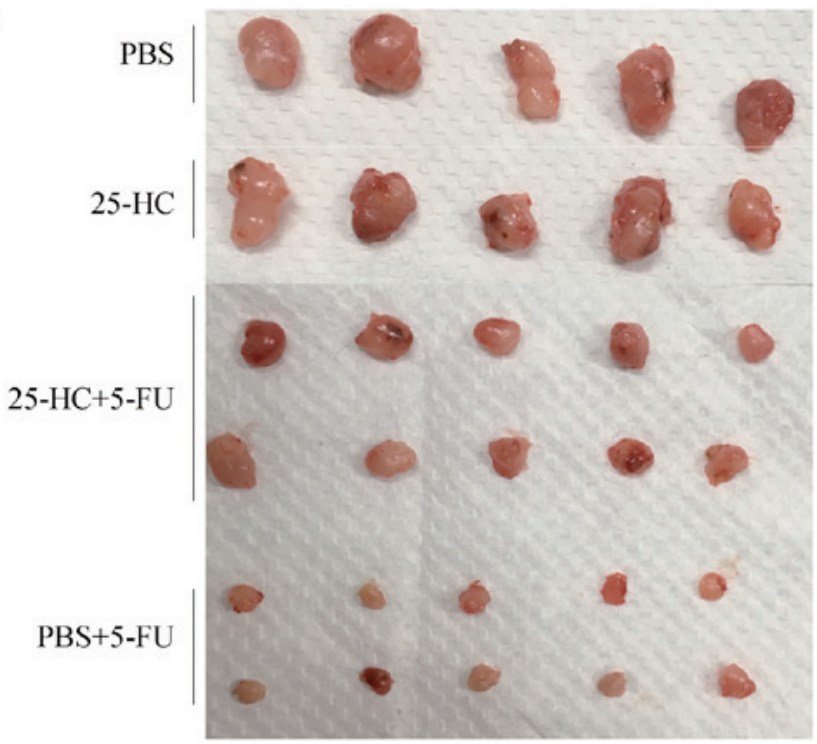

$48 \mathrm{~h}$

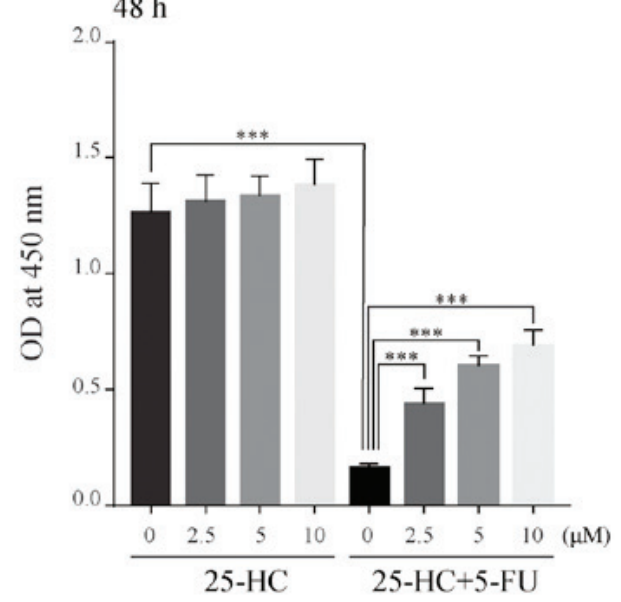

$48 \mathrm{~h}$
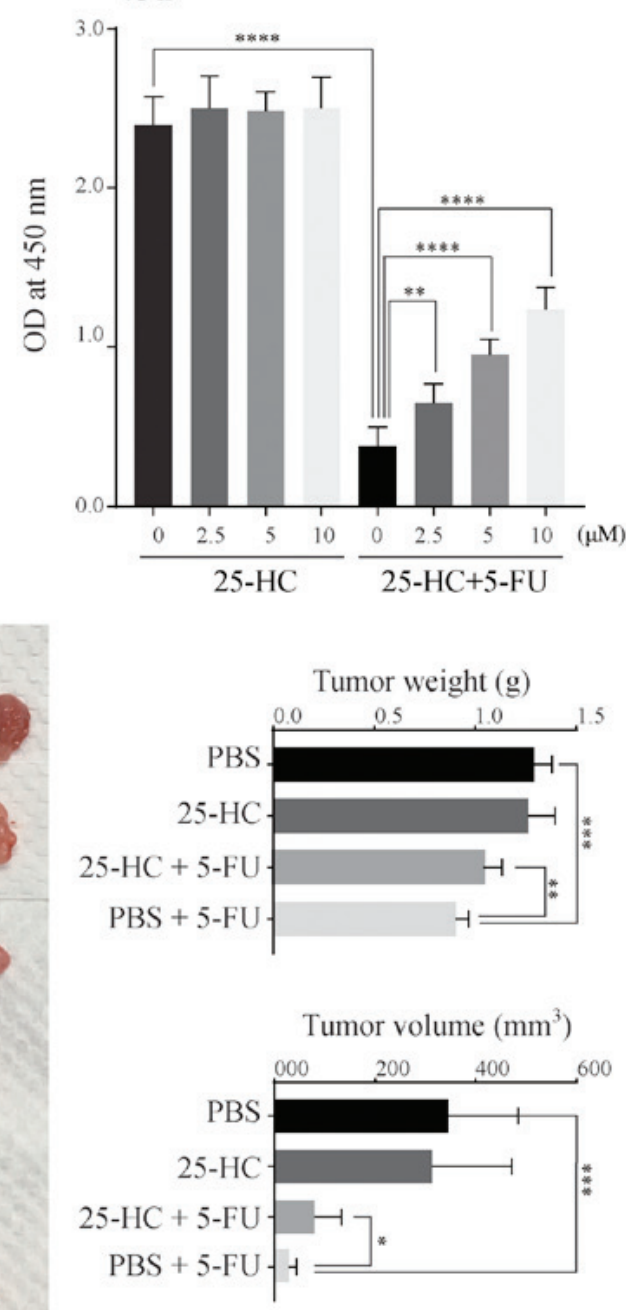

Figure 2. 25-HC decreases the sensitivity of GC cells to 5-FU. (A) AGS cells and MGC-803 were treated with 25 -HC with or without 5-FU (5 $\mu \mathrm{M}$ ) for 24 and $48 \mathrm{~h}$ and cell proliferation was determined by CCK-8 assay. The absorbance at $450 \mathrm{~nm}$ was measured on an ultra-microplate reader. (B) Nude BALB/c mice were injected subcutaneously with AGS cells at $5 \times 10^{6} /$ mouse. When the volumes of tumors reached $100 \mathrm{~mm}^{3}$, the mice were intraperitoneally injected with 5 -FU $(25 \mathrm{mg} / \mathrm{kg})$ or $/$ and $25-\mathrm{HC}(10 \mathrm{mg} / \mathrm{kg})$ every 3 days for 3 weeks. Xenograft tumors were stripped from the nude mice and imaged or tumor weights and tumor volumes were assessed after sacrifice. Results were obtained from 3 independent experiments and are expressed as the means \pm SEM. Statistical significance in (A and B) was determined by one-way ANOVA followed by Dunnett's test and Tukey's test, respectively; ${ }^{*} \mathrm{P}<0.05,{ }^{* *} \mathrm{P}<0.01$ and ${ }^{* * *} \mathrm{P}<0.001$. 25-HC, 25-hydroxycholesterol; GC, gastric cancer.

The results demonstrated that Bay 11-7082 treatment reversed the invasion induced by 25 -HC (Fig. 8A) and abolished the upregulation of MMP expression levels (Fig. 8B). Taken together, these results demonstrated that 25-HC-promoted the invasion of and MMP expression levels in AGS cells by upregulating the NF- $\mathrm{\kappa B}$ signaling pathway. 
A

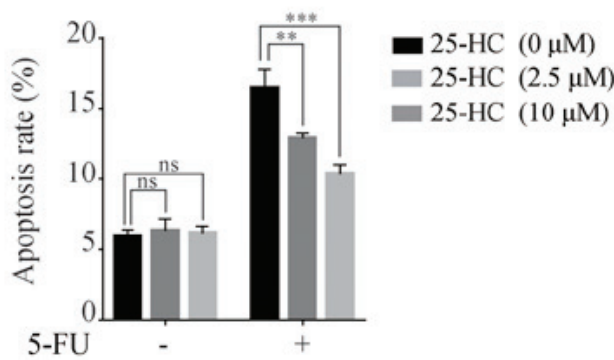

$5-\mathrm{FU}$

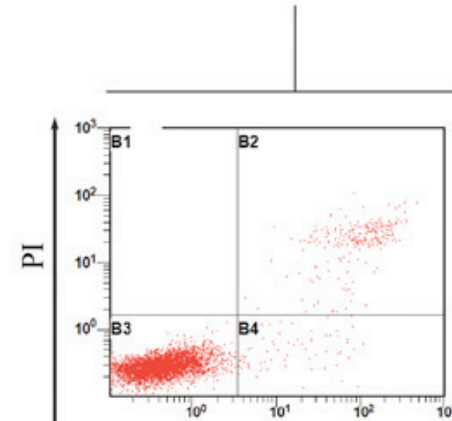

AGS
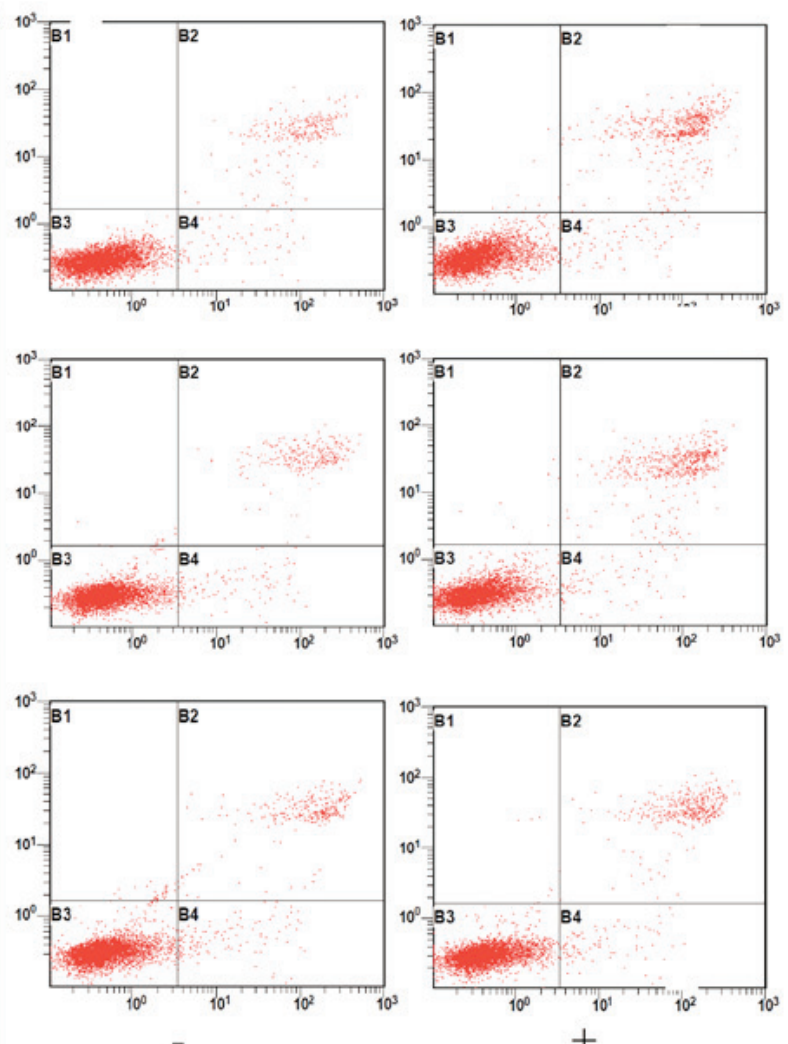

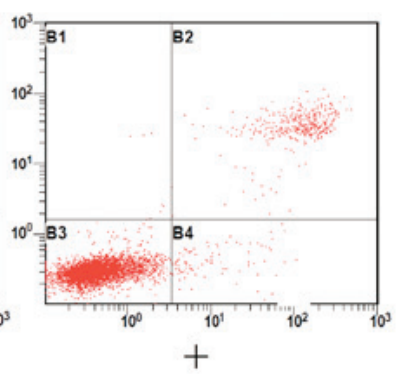

$5-\mathrm{FU}$

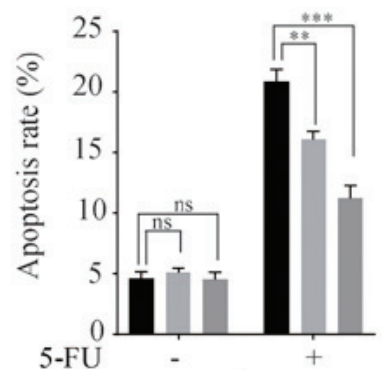

$25-\mathrm{HC}(0 \mu \mathrm{M})$

$25-\mathrm{HC}(2.5 \mu \mathrm{M})$

- $25-\mathrm{HC}(10 \mu \mathrm{M})$

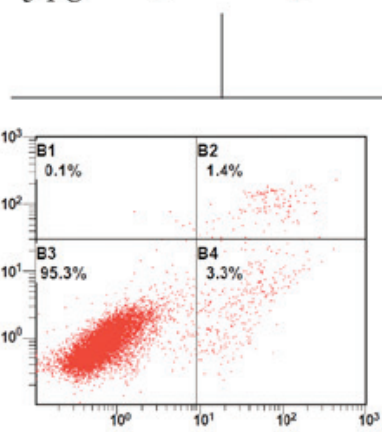

MGC- 803

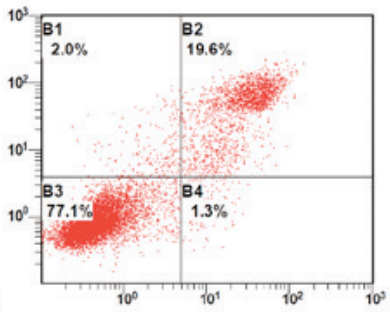

0
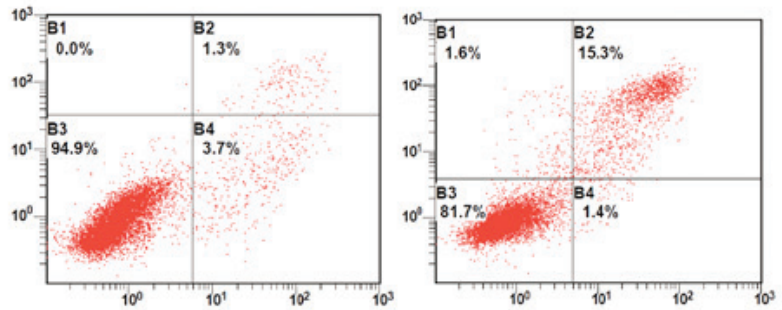

2.5

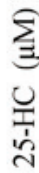
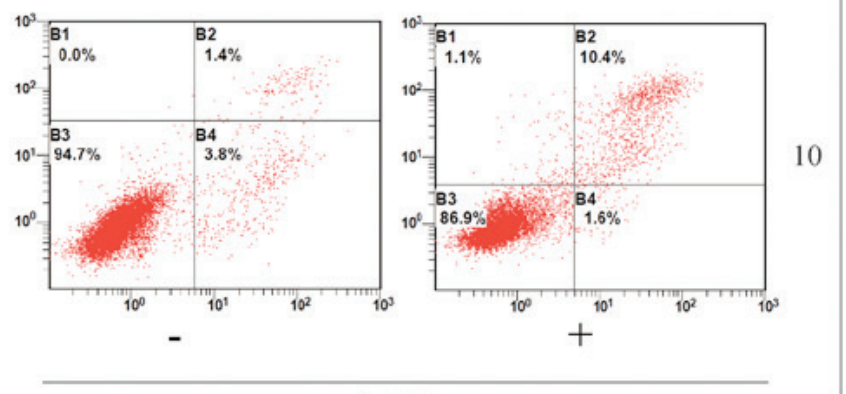

$5-\mathrm{FU}$

Annexin V-FITC

B

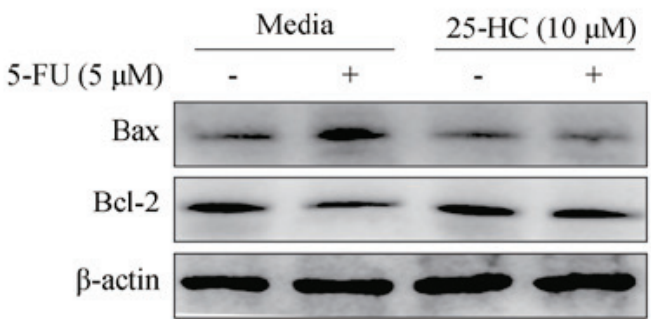

Figure 3. 25-HC decreases the apoptotic effects of 5-FU in GC cells. AGS cells or MGC-803 cells were treated with 25-HC with or without 5-FU (5 $\mu \mathrm{M})$ for 48 h. (A) Cell apoptosis was examined by FITC-Annexin V/PI staining. The statistical analysis of apoptotic AGS cells (FITC ${ }^{+}$) was performed. Treatment with $25-\mathrm{HC}$ at 2.5 and $10 \mu \mathrm{M}$ caused a 3.57 and $6.2 \%$ decrease in the apoptotic fraction of the AGS cells respectively, and 4.77 and $9.63 \%$ decrease of the MGC-803 cells respectively, compared with the control cells. (B) Total cellular proteins in AGS cells treated 25-HC with or without 5-FU (5 $\mu \mathrm{M}$ ) were extracted for western blot analysis to detect the Bcl-2 and Bax expression levels. All the values shown are represented as the means \pm SEM and statistical significance was determined by one-way ANOVA followed by Dunnett's test; ns, no significance, ${ }^{* *} \mathrm{P}<0.01$ and ${ }^{* * *} \mathrm{P}<0.001$. 25-HC, 25-hydroxycholesterol; GC, gastric cancer; 5-FU, 5-fluorouracil.

The promoting effects of 25-HC on AGS cell invasion and MMP expression levels are partly dependent on TLR2. In this study, to investigate whether TLRs are involved in the promoting effects of $25-\mathrm{HC}$ on AGS cell invasion, we first 

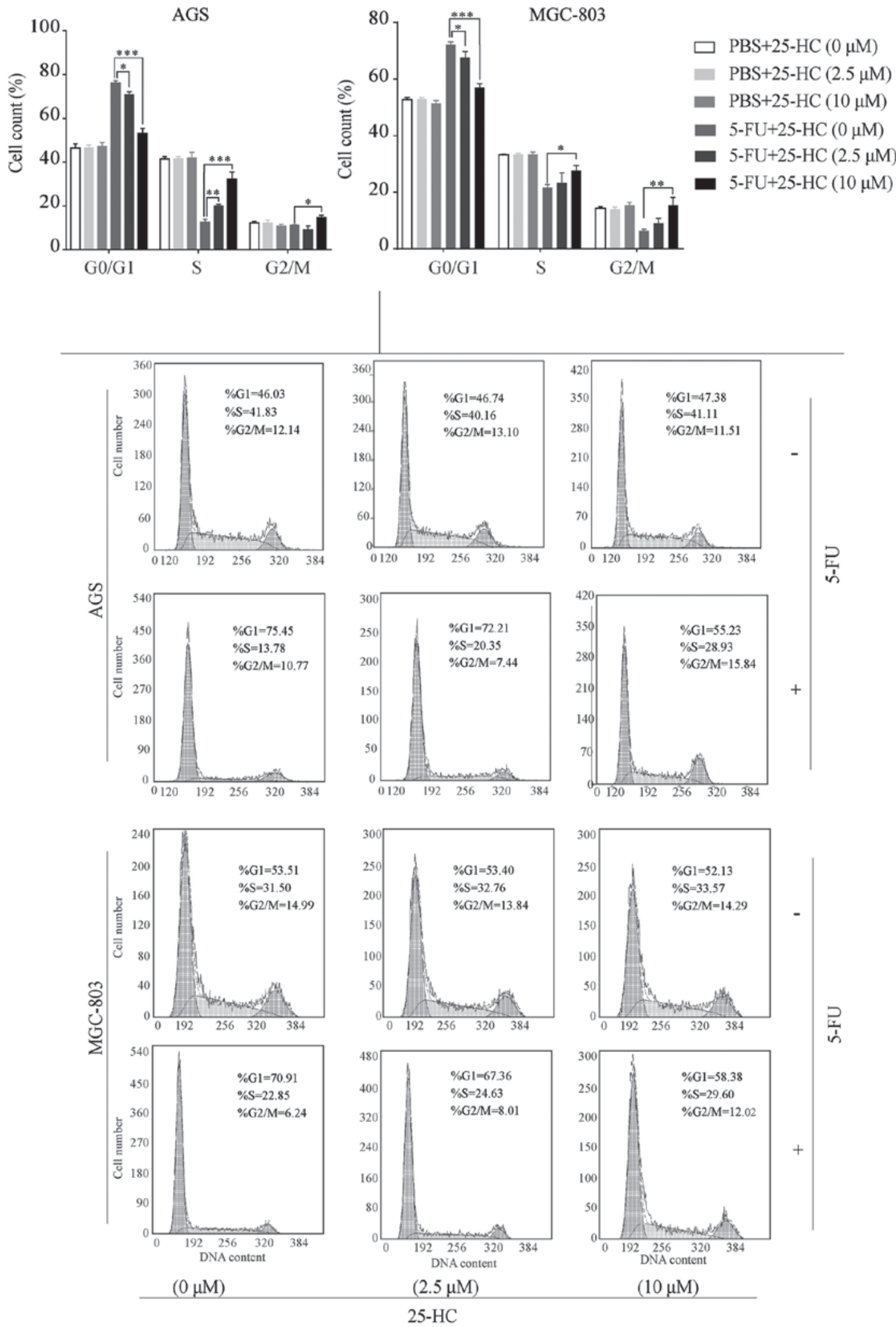

Figure 4. 25-HC arrests the cell cycle of GC cells at S-phase following 5-FU treatment. AGS cells or MGC-803 cells were treated with 25-HC with or without 5 -FU $(5 \mu \mathrm{M})$ for $48 \mathrm{~h}$. Cell cycle distribution was examined by using PI staining and flow cytometry analysis. Representative flow cytometric analysis of cell cycle distribution and the statistical analysis is shown. Results were obtained from 3 independent experiments and are expressed as the means \pm SEM and statistical significance was determined by one-way ANOVA followed by Dunnett's test. Representative images are presented. ${ }^{*} \mathrm{P}<0.05,{ }^{* * *} \mathrm{P}<0.01$ and ${ }^{* * * *} \mathrm{P}<0.001$. 25-HC, 25-hydroxycholesterol; GC, gastric cancer.

detected the expression levels of TLRs by RT-qPCR (Fig. 9A) and western blot analysis (Fig. 9B). The results revealed that
25-HC significantly induced TLR2 expression in the AGS cells in a time- and dose-dependent manner, while it had no effects 
A

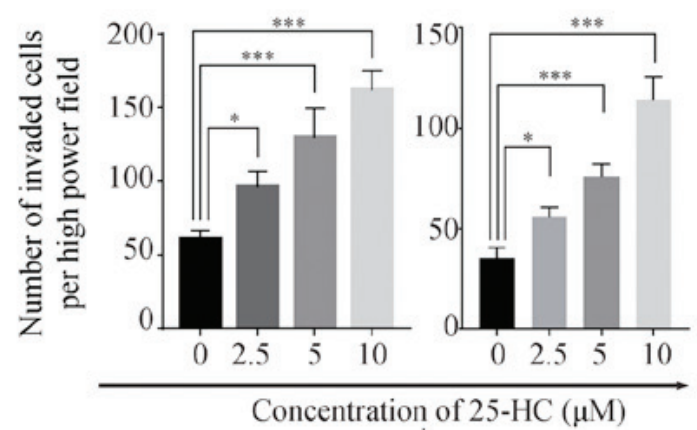

B

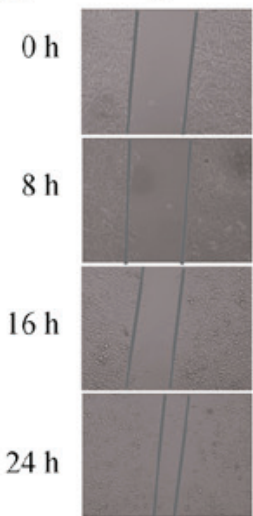

2.5

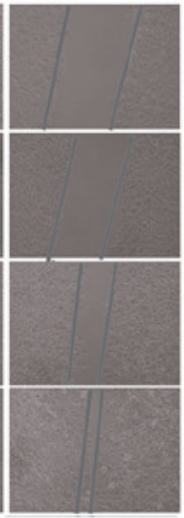

5

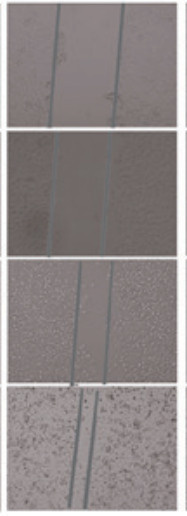

$10 \quad 25-\mathrm{HC}(\mu \mathrm{M})$

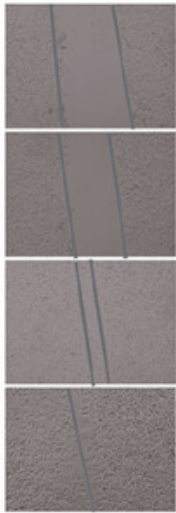

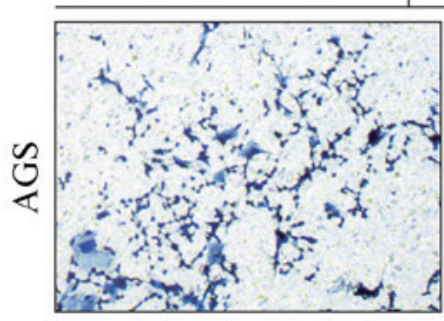
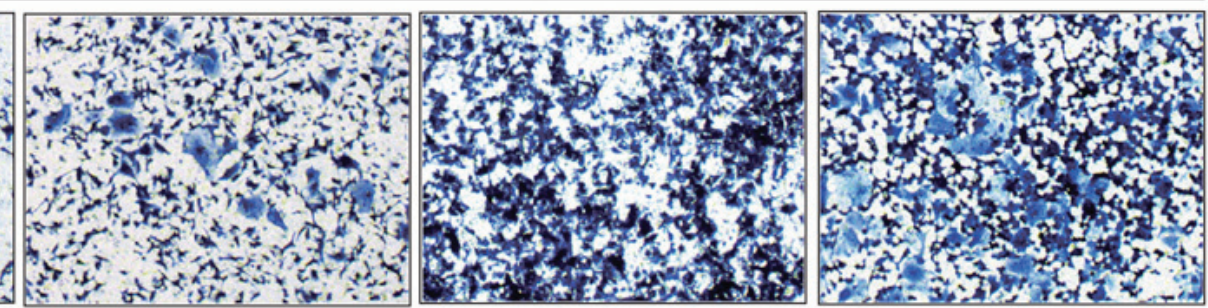

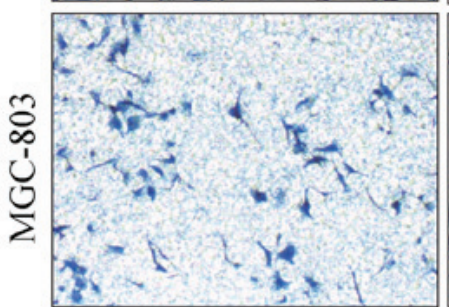

$25-\mathrm{HC}(0 \mu \mathrm{M})$

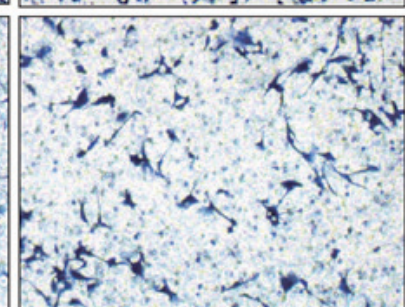

$25-\mathrm{HC}(2.5 \mu \mathrm{M})$

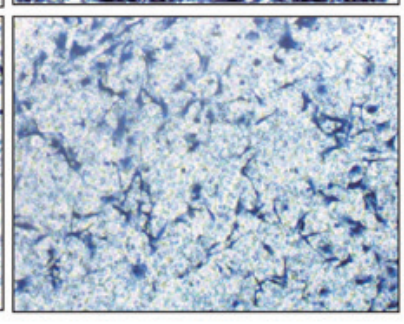

$25-\mathrm{HC}(5 \mu \mathrm{M})$

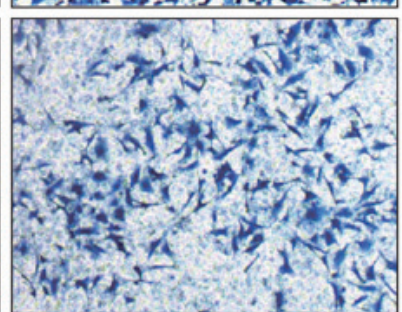

$25-\mathrm{HC}(10 \mu \mathrm{M})$

C
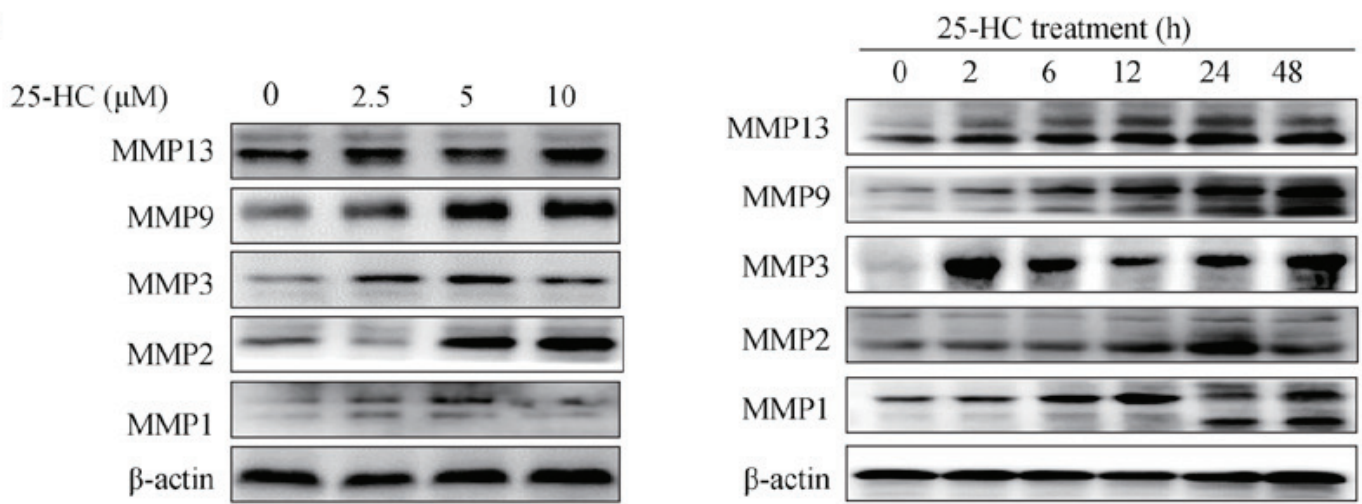

Figure 5. 25-HC promotes GC cell migration and invasion in vitro. (A) Invasion assays of AGS cells or MGC-803 cells treated with various concentrations of 25 -HC were performed using cell culture chambers with $8-\mu$ m pore filter. After $36 \mathrm{~h}$, the cells invaded to the underside of the membrane were quantitated by cell counting in 5 pre-determined fields. (B) The migratory ability of the AGS cells was determined by wound healing assay. Monolayers of AGS cells were wounded by a 200- $\mu \mathrm{l}$ plastic tip and then incubated for a further $24 \mathrm{~h}$ in $5 \%$ FBS medium with different concentrations of 25 -HC. (C) AGS cells were treated with the indicated concentrations of $25-\mathrm{HC}$ for $24 \mathrm{~h}$ or were treated with $5 \mu \mathrm{M} 25-\mathrm{HC}$ for the indicated times before total cellular proteins were extracted for western blot analysis to detect the MMPs expressions. Results were obtained from 3 independent experiments and are expressed as the means \pm SEM and statistical significance was determined by one-way ANOVA followed by Dunnett's test. Representative images are presented. ${ }^{*} \mathrm{P}<0.05$ and ${ }^{* * *} \mathrm{P}<0.001$. 25-HC, 25-hydroxycholesterol; GC, gastric cancer.

on the TLR3, 4 and 9 expression levels. We then knocked down TLR2 in the AGS cells by siRNA transfection and the knock down efficiency was shown in Fig. 9D. As shown in Fig. 9C, the knockdown of TLR2 partly abolished the 25-HC-induced cell invasion. In addition, the expression levels of MMPs were also decreased by the knockdown of TLR2 (Fig. 9D). We also noted that the knockdown of TLR2 only partly decreased the 25-HC-induced AGS cell migration and MMP expression levels. Thus, we speculated that TLR2 is not the only signaling pathway responsible for 25-HC-promoted AGS cells invasion and MMPs expressions.

\section{Discussion}

25-HC is one of the major cytotoxins in oxidized low-density lipoprotein (oxLDL) and has been demonstrated to exert 
A
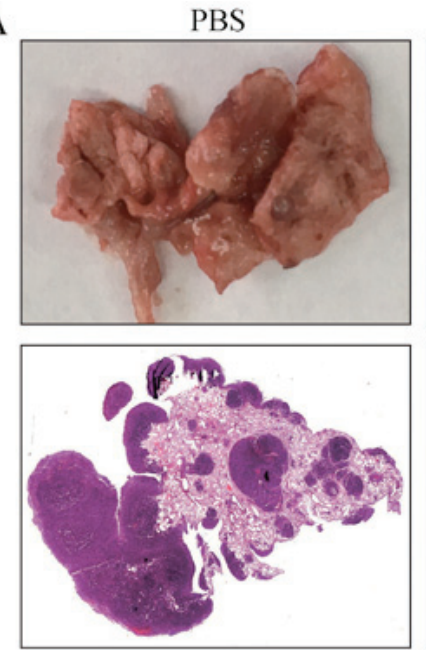
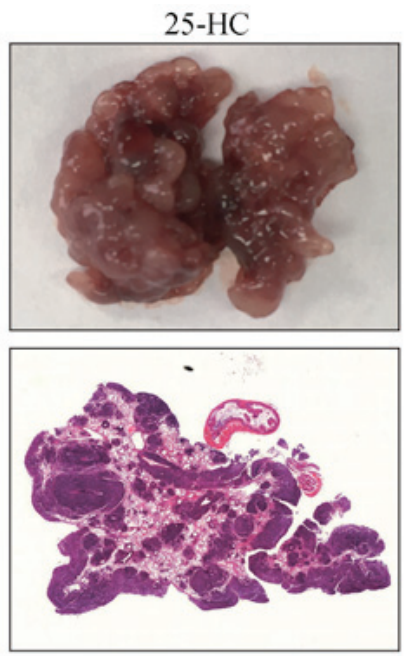
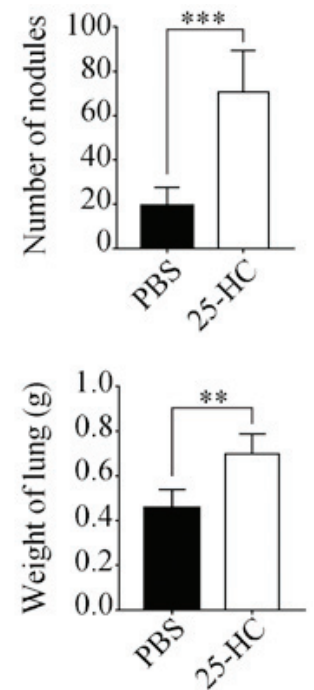

B

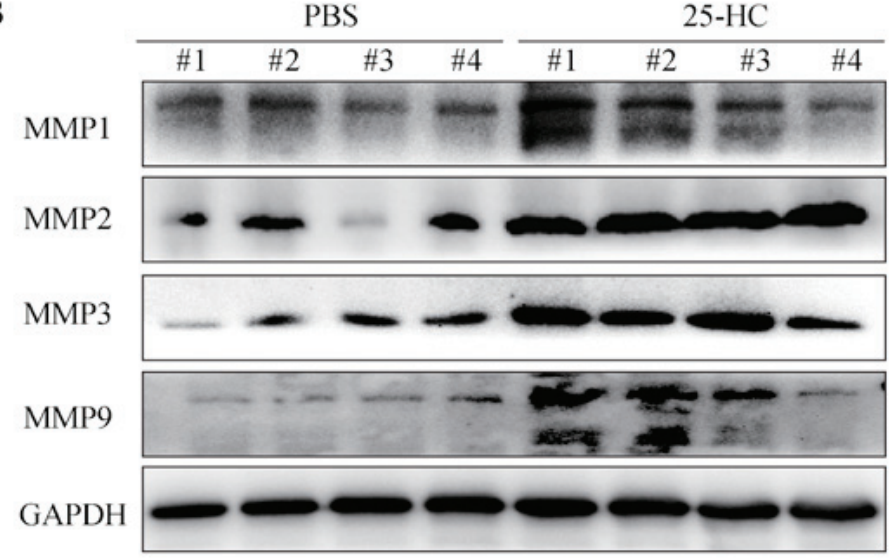

Figure 6. 25-HC promotes lung metastasis in vivo. (A) Nude BALB/c mice were injected with AGS cells through the tail vein and randomly divided into the PBS and 25-HC groups. Mice in the 25-HC group were intraperitoneally injected with 25 -HC (10 mg/kg) every 3 days. After 3 weeks, the mice were sacrificed, and lungs were removed and weighed. The lung metastatic tumors on the surface were calculated and H\&E staining was performed. (B) Proteins were extracted from the lung tissues for western blot analysis to determine the MMP expression levels. Results were obtained from 2 independent experiments and are expressed as the means \pm SEM. Statistical significance was determined by Student's t-test. Representative images are presented. ${ }^{* *} \mathrm{P}<0.01$ and ${ }^{* * * *} \mathrm{P}<0.001$. 25-HC, 25-hydroxycholesterol; GC, gastric cancer; MMP, matrix metalloproteinase.

dose-dependent effects on cell proliferation (32) and the induction of cell apoptosis (33-35). However, little is known about the role of 25-HC in GC. In this study, we demonstrated that 25-HC significantly decreased the sensitivity of AGS and MGC-803 cells to 5-FU, whereas it had no direct effects on cell proliferation and apoptosis. Moreover, $25-\mathrm{HC}$ treatment led to the enhanced invasion of GC cells, accompanied by the increased expression levels of MMPs. Further investigations revealed that $25-\mathrm{HC}$ promoted cells invasion via the TLR2-mediated activation of the NF- $\mathrm{kB}$ signaling pathway. These results provide new insight into the roles of $25-\mathrm{HC}$ in GC progression.

The results of the present study are inconsistent with prior studies, since we reported that $25-\mathrm{HC}$ had no direct effects on cell proliferation and apoptosis. We speculate that there are two reasons for this. One reason is that the effector cells are different since other studies were performed on non-tumor cells, including macrophages, vascular cells and differentiated PG12 cells (33-35) and perhaps these cells are more sensitive to $25-\mathrm{HC}$ treatment. The other reason may be the different concentrations of $25-\mathrm{HC}$ used in this study. Chen et al also reported 25-HC promoted A549 and NCL-H1975 lung adenocarcinoma and cell migration and invasion at the concentration of $0.1 \mu \mathrm{M}$ without affecting cell proliferation, while displaying the inhibitory effect on cell proliferation from 1.0-25 $\mu \mathrm{M}$ (18), indicating that 25-HC plays differential roles at various concentrations. In this study, we reported that 25-HC promoted the migration and invasion of GC cells at the concentrations from $2.5-10 \mu \mathrm{M}$ without affecting cell proliferation.

$\mathrm{NF}-\mathrm{\kappa B}$ is constitutively activated in many types of cancer and exerts a variety of pro-tumorigenic effects $(36,37)$. A previous study reported that $25-\mathrm{HC}$ amplified inflammatory signaling by mediating the recruitment of the AP-1 components FBJ osteosarcoma oncogene (FOS) and jun proto-oncogene (JUN) to the promoters of a subset of Toll-like receptor-responsive genes, resulting in the alteration of the inflammatory response (38). 25-HC can enhance the NF- $\kappa \mathrm{B}$ DNA binding activity and the translocation of phosphorylated c-Jun into the nucleus (39). The activation of NF- $\mathrm{KB}$ is involved in the induction of the MMPs which are associated with the invasion and metastasis of tumor cells. Thus, the activated NF- $\mathrm{kB}$ signaling and the upregulated MMP expression levels following treatment with 25-HC 
A

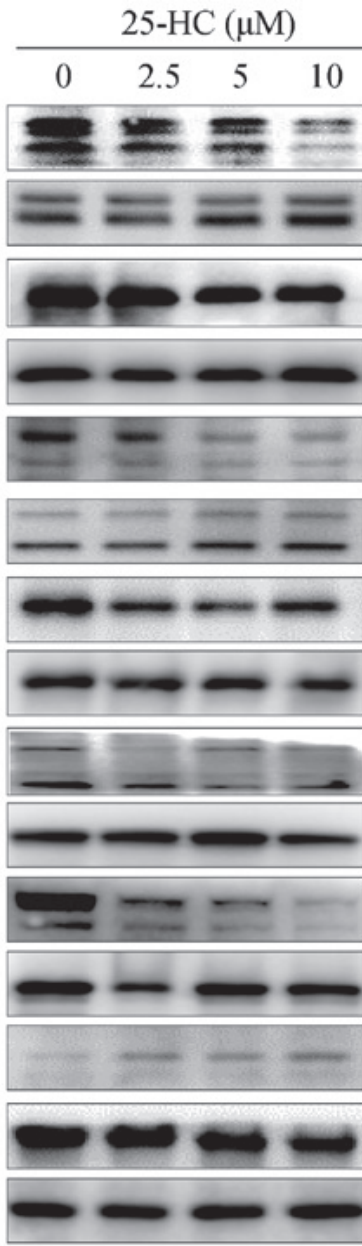

25-HC treatment (h)

\begin{tabular}{llllll}
\hline 0 & 2 & 6 & 12 & 24 & 48
\end{tabular}

p-Erk1/2

Erk1/2

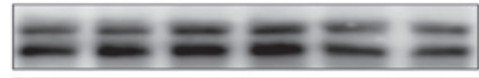

Erk1/2

$= \pm==$

p-p38

p38

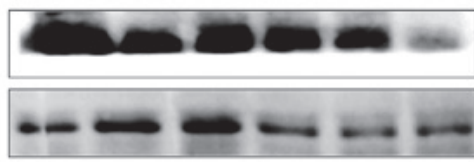

$\mathrm{p}-\mathrm{SAPK} / \mathrm{JNK}$

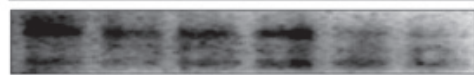

SAPK/JNK

p-AKT

AKT
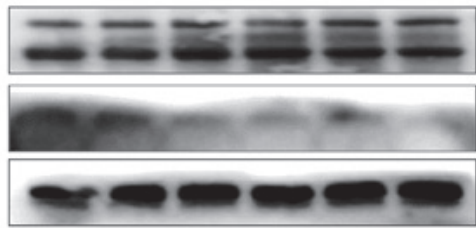

$\mathrm{p}-\mathrm{PI} 3 \mathrm{~K}$ p $85 / \mathrm{p} 55$

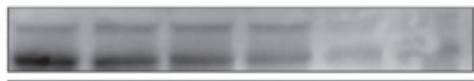

PI3K p85

p-STAT3

STAT3

p-NF- $\kappa$ B p 65

NF-אB p 65

$\beta$-actin
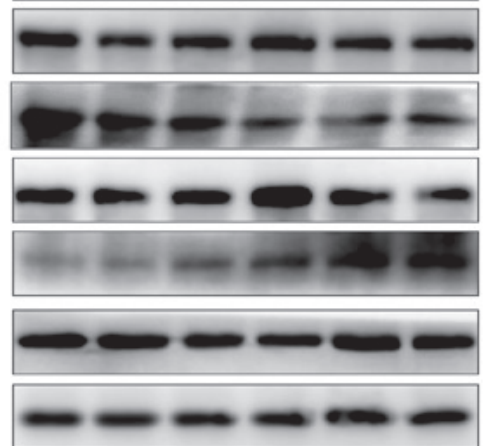

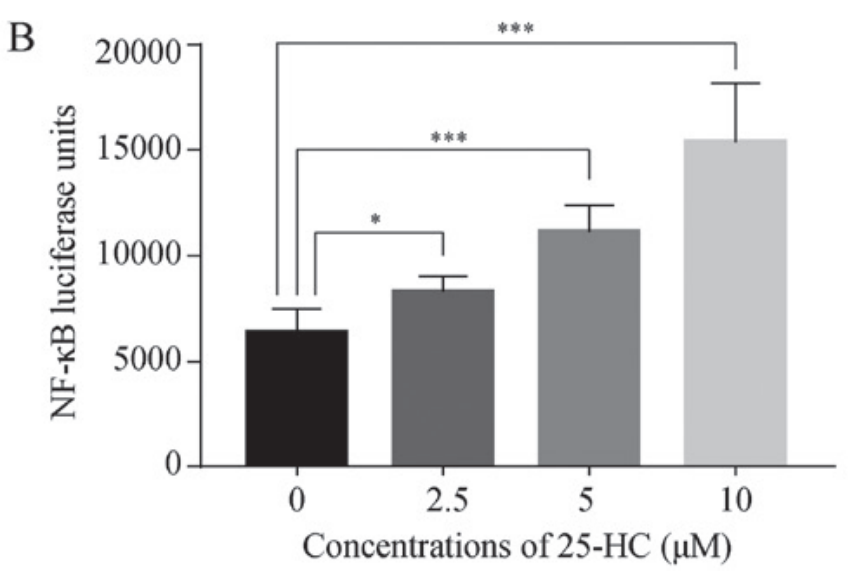

Figure 7. 25-HC regulates multiple signaling pathways. (A) AGS cells were treated with the indicated concentrations of $25-\mathrm{HC}$ for $24 \mathrm{~h}$ or treated with $5 \mu \mathrm{M}$ $25-\mathrm{HC}$ for the indicated times before total cellular proteins were extracted for western blot analysis to detect the p-Erk1/2, Erk1/2, p-p38, p38, p-SAPK/JNK, SAPK/JNK, p-AKT, AKT, p-PI3K p85/p55, PI3K p85/p55, p-STAT3, STAT3, p-NF-кB p65, NF-кB p65 expression levels. Results were representative of 3 independent experiments. (B) AGS cells were transfected with NF- $\mathrm{kB}$ luciferase reporter plasmid before the cells were treated with $25-\mathrm{HC}$. After $24 \mathrm{~h}$, the luciferase activities were determined by using the Bright-Glo luciferase assay system. Results were obtained from 3 independent experiments and are expressed as the means \pm SEM. Statistical significance was determined by one-way ANOVA followed by Dunnett's test. Representative images are presented. "P<0.05 and ${ }^{* * * * *} \mathrm{P}<0.001$. 25-HC, 25-hydroxycholesterol; GC, gastric cancer.

in this study could be expected. It has been proven that the activation of NF- $\kappa B$ promotes GC cell proliferation (40). As shown in Figs. 7 and 8, the promotion of the invasion of $\mathrm{GC}$ cells by $25-\mathrm{HC}$ was dependent on the NF- $\mathrm{\kappa B}$ signaling pathway. It is noteworthy that $25-\mathrm{HC}$ had no effects on cell proliferation, as shown in Fig. 1. Thus, we detected stem cell marker expression in AGS cells treated with 25-HC (Fig. S1), and the results revealed that $25-\mathrm{HC}$ had no effects on the expression levels of CD44, ALDH1, Sox 2 and KLF4. We assumed that the probable reason for this was that the effects of $25-\mathrm{HC}$ are complex. Reboldi et al found that $25-\mathrm{HC}$ decreased inflammasome activation in macrophages and consequently decreased the expression of IL- $1 \beta$ and caspase- 1 activation (41) and Tricarico et al reported that 25-HC reduced 
A

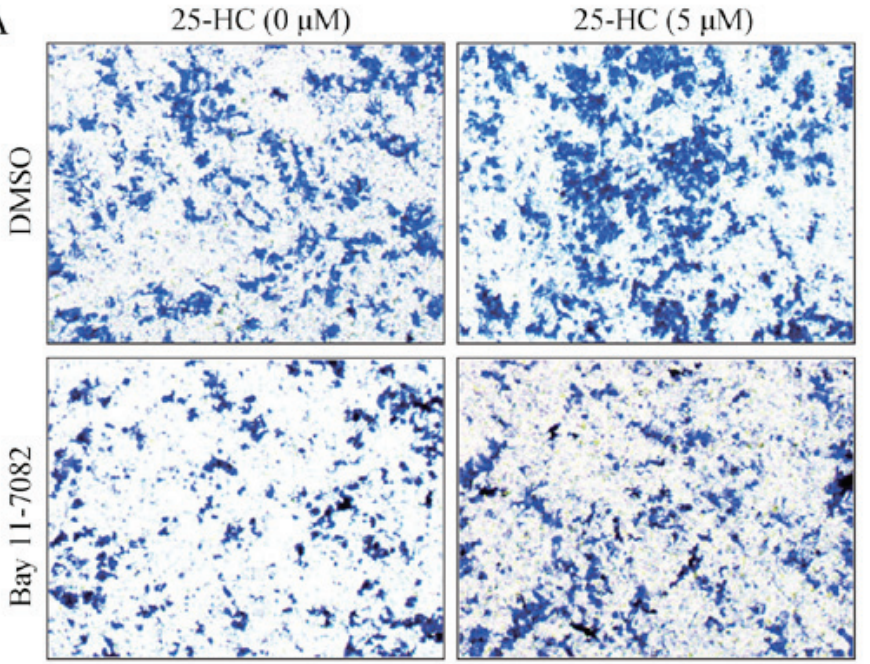

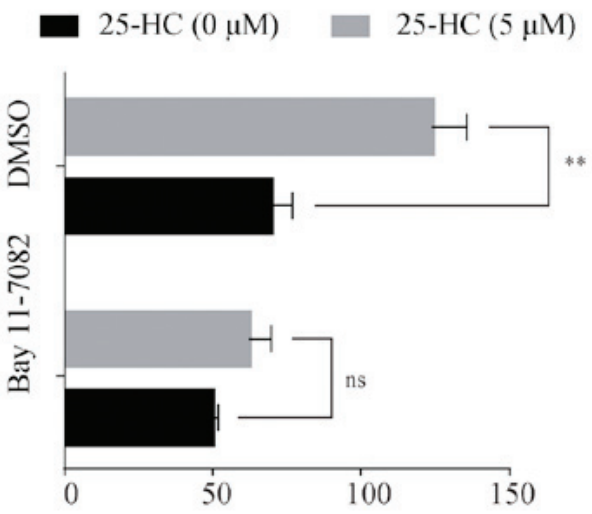

Number of invaded cells per high power field

B

DMSO

Bay 11-7082

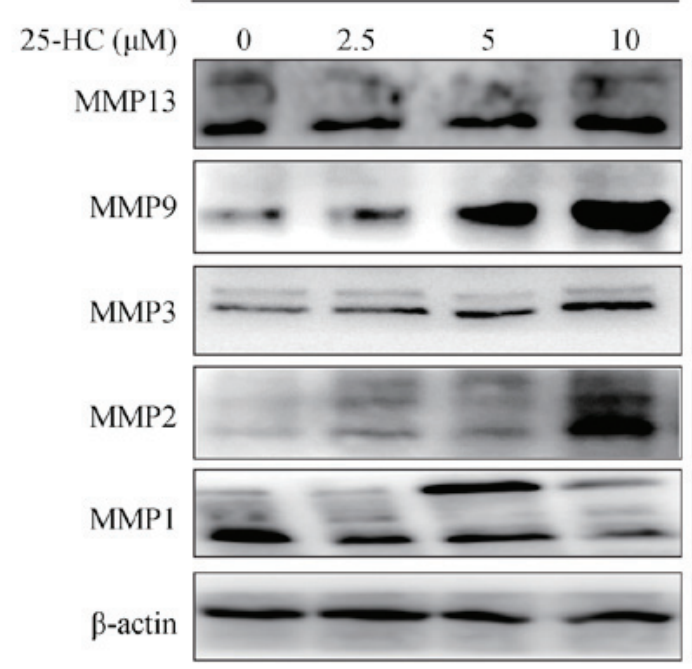

\begin{tabular}{|rrrr}
0 & 2.5 & 5 & 10 \\
\hdashline & & - & - \\
\hline & & - & -
\end{tabular}
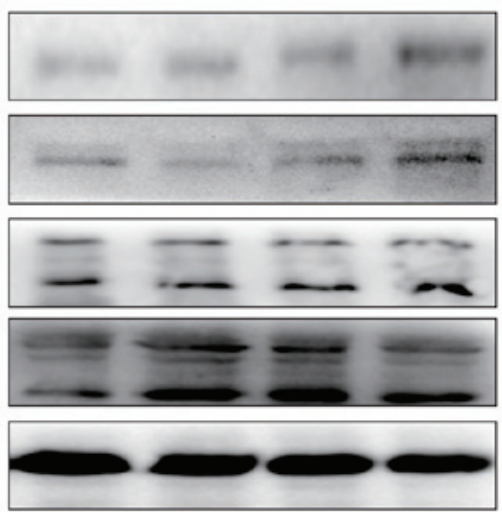

Figure 8. 25-HC promotes AGS cell invasion and MMP expression through the upregulation of the NF-kB pathway. (A) AGS cells in the upper chamber were pre-treated with Bay 11-7082 (2 $\mu \mathrm{g} / \mathrm{ml})$ for $1 \mathrm{~h}$ and the medium were replaced with FBS-free medium supplemented with $25-\mathrm{HC}$ or not. After $36 \mathrm{~h}$, the cells invaded to the underside of the membrane were quantitated by cell counting in 5 pre-determined fields. (B) AGS cells were pre-treated with Bay 11-7082 for $1 \mathrm{~h}$ followed by the treatment with the indicated concentrations of $25-\mathrm{HC}$ for $24 \mathrm{~h}$. Total cellular proteins were extracted for western blot analysis to detect the MMP expression levels. Results were obtained from 3 independent experiments and expressed as the means \pm SEM. Statistical significance was determined by a Student's t-test. Representative images are presented; ns, no significance, ${ }^{* * *} \mathrm{P}<0.01 .25-\mathrm{HC}, 25$-hydroxycholesterol; GC, gastric cancer; MMP, matrix metalloproteinase.

inflammation, but was ineffective in restoring the autophagic flux and decreasing the apoptotic levels (42). All these controversial findings suggest that the effects of $25-\mathrm{HC}$ are complex. Thus, we have reasons to assume that $25-\mathrm{HC}$ may exert inhibitory effects on the activation of other signaling pathways, such as the Wnt or Hedgehog pathways (43) which could affect cell proliferation and apoptosis.

Oxysterols, including $7 \beta$-hydroxycholesterol ( $7 \beta-\mathrm{OHC})$ has been reported to enhance the sensitivity of tumor cell lines, such as HepG2, U937 and K562 to adriamycin, VP-16, 5-FU and bleomycin (44). In this study, having determined that 25-HC had no direct effects on AGS and MGC-803 cell proliferation (Fig. 1), we thus detected whether 25-HC affects the sensitivity of GC cells to 5-FU. As shown in Fig. 3, 25-HC decreased the sensitivity of GC cells to 5-FU. To the best of our knowledge, this is a novel finding of this study.
To the best of our knowledge, there is limited research available on the association between 25-HC and TLRs. Erridge et al reported that in THP-1 cells, 25-HC stimulated inflammatory signaling via the lipid-recognizing TLRs 1, 2, 4 and 6, while independent of TLR signaling (45). In addition, TLR4 agonist can induce the synthesis of 25-HC in macrophages (46). In this study, we detected the expression levels of TLR2, TLR3, TLR4 and TLR9, which have been reported to be expressed in GC cells (47-50). The results of this study revealed that 25-HC upregulated TLR2 expression; however, the exact mechanisms involved are not yet clear and want further investigation. To the best of our knowledge, this is the first study to report the regulation of TLRs by $25-\mathrm{HC}$.

In conclusion, in this study, we identified a novel role of $25-\mathrm{HC}$ in $\mathrm{GC}$, in that $25-\mathrm{HC}$ promotes GC cell migration and invasion by upregulating TLR2-NF- $\kappa$ B-mediated MMP 
A

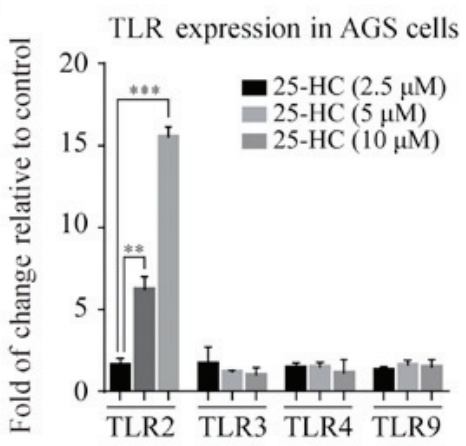

$\mathrm{D}$

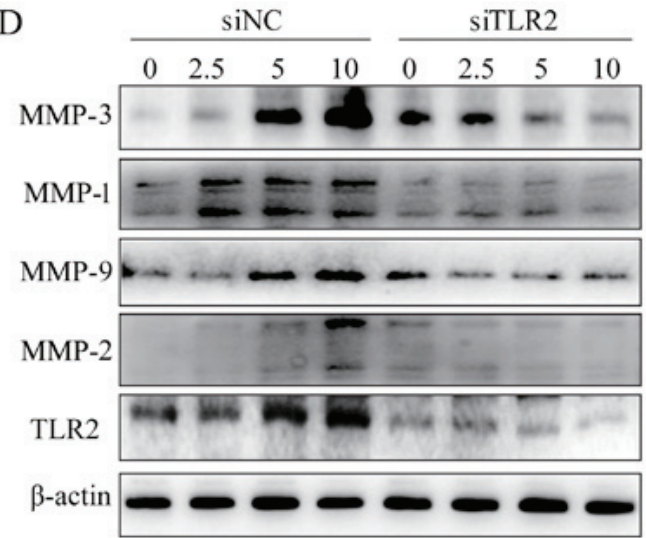

25-HC treatment (h)

B

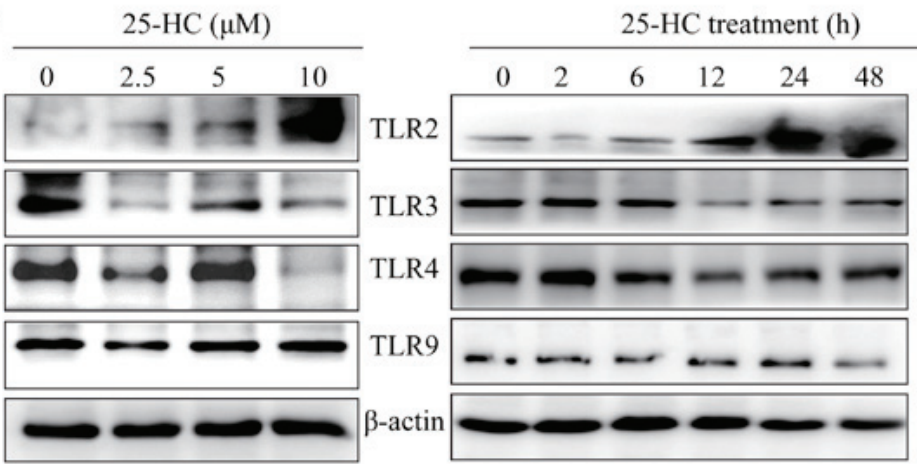

$\mathrm{C}$

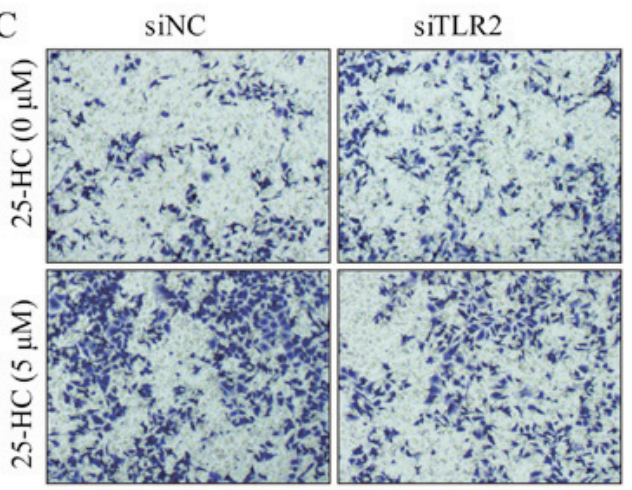

$25-\mathrm{HC}(0 \mu \mathrm{M})=25-\mathrm{HC}(5 \mu \mathrm{M})$

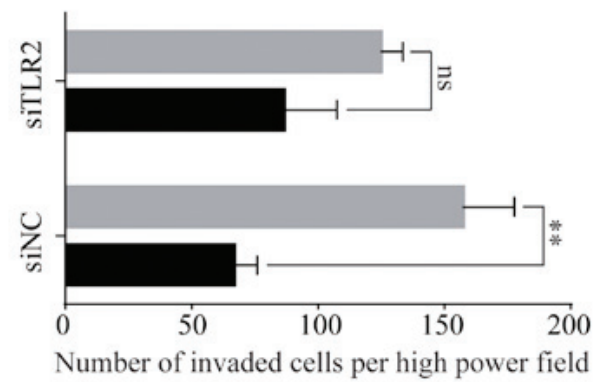

Figure 9. 25-HC-promotes AGS cell invasion and MMP expression and these effects are partly dependent on TLR2. (A) AGS cells were treated with the indicated concentrations of $25-\mathrm{HC}$ for $24 \mathrm{~h}$ before the cells were collected, RNA was extracted for RT-qPCR to determine the mRNA expression levels of TLR2, TLR3, TLR4 and TLR9. Statistical significance was determined by one-way ANOVA followed by Dunnett's test. (B) AGS cells were treated with the indicated concentrations of $25-\mathrm{HC}$ for $24 \mathrm{~h}$ or treated with $5 \mu \mathrm{M} 25-\mathrm{HC}$ for the indicated times before total cellular proteins were extracted for western blot analysis to detect the TLR2, TLR3, TLR4 and TLR9 expression levels. AGS cells were transfected with siNC or siTLR2 for $24 \mathrm{~h}$. (C) Invasion assay was carried out following stimulation with $5 \mu \mathrm{M} 25$-HC. Statistical significance was determined by a Student's t-test. (D) Cells were treated with various concentrations of 25-HC for $24 \mathrm{~h}$ before total cellular proteins were extracted for western blot analysis to detect the MMP and TLR2 expression levels. Results were obtained from 3 independent experiments and are expressed as the means \pm SEM. Representative images are presented; ns, no significance; ${ }^{* * *} \mathrm{P}<0.01$ and ${ }^{* * * *} \mathrm{P}<0.001$. 25-HC, 25-hydroxycholesterol; GC, gastric cancer; MMP, matrix metalloproteinase; TLR, Toll-like receptor.

expression. Therefore, the targeting of 25-HC may prove to be a potential therapeutic strategy for the treatment of GC.

\section{Acknowledgements}

Not applicable.

\section{Funding}

The present study was supported by a grant from the Key Project of Natural Science Foundation of Zhejiang Province (LZ16H160003 to WC).

\section{Availability of data and materials}

All data generated or analyzed during this study are included in this published article or are available from the corresponding author on reasonable request.

\section{Authors' contributions}

SW and WC participated in the conception and design of the study. SW, YY, CR and GZ performed the statistical analysis and were involved in the preparation of the figures. SW and YY reviewed the results and participated in the discussion of 
the data. SW, GZ and WC prepared the manuscript and revised it. All authors have read and approved the final manuscript.

\section{Ethics approval and consent to participate}

All the experiments using animals were approved by the Animal Care and Use Committee of Zhejiang University.

\section{Patient consent for publication}

Not applicable.

\section{Competing interests}

The authors declare that they have no competing interests.

\section{References}

1. Kloudova A, Guengerich FP and Soucek P: The role of oxysterols in human cancer. Trends Endocrinol Metab 28: 485-496, 2017.

2. Nelson ER, Chang CY and McDonnell DP: Cholesterol and breast cancer pathophysiology. Trends Endocrinol Metab 25: 649-655, 2014.

3. Kang KA, Chae S, Lee KH, Park MT, Lee SJ, Lee YS and Hyun JW: Cytotoxic effect of 7beta-hydroxycholesterol on human NCI-H460 lung cancer cells. Biol Pharm Bull 28: 1377-1380, 2005.

4. Nagano K, Imai S, Zhao X, Yamashita T, Yoshioka Y, Abe Y, Mukai Y,Kamada H,Nakagawa S, Tsutsumi Y, et al: Identification and evaluation of metastasis-related proteins, oxysterol binding protein-like 5 and calumenin, in lung tumors. Int J Oncol 47: 195-203, 2015.

5. Torre LA, Bray F, Siegel RL, Ferlay J, Lortet-Tieulent J and Jemal A: Global cancer statistics, 2012. CA Cancer J Clin 65 87-108, 2015

6. Chen W, Zheng R, Baade PD, Zhang S, Zeng H, Bray F, Jemal A, $\mathrm{Yu}$ XQ and He J: Cancer statistics in China, 2015. CA Cancer J Clin 66: 115-132, 2016.

7. Karimi P, Islami F, Anandasabapathy S, Freedman ND and Kamangar F: Gastric cancer: Descriptive epidemiology, risk factors, screening, and prevention. Cancer Epidemiol Biomarkers Prev 23: 700-713, 2014.

8. Kitayama J, Hatano K, Kaisaki S, Suzuki H, Fujii S and Nagawa H: Hyperlipidaemia is positively correlated with lymph node metastasis in men with early gastric cancer. Br J Surg 91: 191-198, 2004.

9. Guo E, Chen L, Xie Q, Chen J, Tang Z and Wu Y: Serum HDL-C as a potential biomarker for nodal stages in gastric cancer. Ann Surg Oncol 14: 2528-2534, 2007.

10. Chen G, Feng W, Zhang S, Bian K, Yang Y, Fang C, Chen M, Yang J and Zou X: Metformin inhibits gastric cancer via the inhibition of HIF1 $\alpha / P K M 2$ signaling. Am J Cancer Res 5: 1423-1434, 2015.

11. Valaee S, Yaghoobi MM and Shamsara M: Metformin inhibits gastric cancer cells metastatic traits through suppression of epithelial-mesenchymal transition in a glucose-independent manner. PLoS One 12: e0174486, 2017.

12. Singh PP and Singh S: Statins are associated with reduced risk of gastric cancer: A systematic review and meta-analysis. Ann Oncol 24: 1721-1730, 2013.

13. Russell DW: The enzymes, regulation, and genetics of bile acid synthesis. Annu Rev Biochem 72: 137-174, 2003.

14. Johnson KA, Morrow CJ, Knight GD and Scallen TJ: In vivo formation of 25-hydroxycholesterol from endogenous cholestero after a single meal, dietary cholesterol challenge. J Lipid Res 35: 2241-2253, 1994.

15. Hodis HN, Chauhan A, Hashimoto S, Crawford DW and Sevanian A: Probucol reduces plasma and aortic wall oxysterol levels in cholesterol fed rabbits independently of its plasma cholesterol lowering effect. Atherosclerosis 96: 125-134, 1992.

16. Lappano R, Recchia AG, De Francesco EM, Angelone T, Cerra MC, Picard D and Maggiolini M: The cholesterol metabolite 25-hydroxycholesterol activates estrogen receptor $\alpha$-mediated signaling in cancer cells and in cardiomyocytes. PLoS One 6: e16631, 2011.
17. Simigdala N, Gao Q, Pancholi S, Roberg-Larsen H, Zvelebil M, Ribas R, Folkerd E, Thompson A, Bhamra A, Dowsett M, et al: Cholesterol biosynthesis pathway as a novel mechanism of resistance to estrogen deprivation in estrogen receptor-positive breast cancer. Breast Cancer Res 18: 58, 2016.

18. Chen L, Zhang L, Xian G, Lv Y, Lin Y and Wang Y: 25-Hydroxycholesterol promotes migration and invasion of lung adenocarcinoma cells. Biochem Biophys Res Commun 484: 857-863, 2017.

19. Burkard I, von Eckardstein A, Waeber G, Vollenweider P and Rentsch KM: Lipoprotein distribution and biological variation of 24S- and 27-hydroxycholesterol in healthy volunteers. Atherosclerosis 194: 71-78, 2007.

20. Yang P, Zhou Y, Chen B, Wan HW, Jia GQ, Bai HL and Wu XT: Overweight, obesity and gastric cancer risk: Results from a meta-analysis of cohort studies. Eur J Cancer 45: 2867-2873, 2009.

21. Livak KJ and Schmittgen TD: Analysis of relative gene expression data using real-time quantitative PCR and the 2(-Delta Delta C(T)) Method. Methods 25: 402-408, 2001.

22. Gilkes DM, Semenza GL and Wirtz D: Hypoxia and the extracellular matrix: Drivers of tumour metastasis. Nat Rev Cancer 14: 430-439, 2014.

23. Høye AM and Erler JT: Structural ECM components in the premetastatic and metastatic niche. Am J Physiol Cell Physiol 310: C955-C967, 2016.

24. Yadav L, Puri N, Rastogi V, Satpute P, Ahmad R and Kaur G: Matrix metalloproteinases and cancer - roles in threat and therapy. Asian Pac J Cancer Prev 15: 1085-1091, 2014.

25. Murray GI, Duncan ME, Arbuckle E, Melvin WT and Fothergill JE: Matrix metalloproteinases and their inhibitors in gastric cancer. Gut 43: 791-797, 1998.

26. Elnemr A, Yonemura Y, Bandou E, Kinoshita K, Kawamura T, Takahashi S, Tochiori S, Endou Y and Sasaki T: Expression of collagenase-3 (matrix metalloproteinase-13) in human gastric cancer. Gastric Cancer 6: 30-38, 2003.

27. Yang $M$ and Huang CZ: Mitogen-activated protein kinase signaling pathway and invasion and metastasis of gastric cancer. World J Gastroenterol 21: 11673-11679, 2015.

28. Kanda N, Seno H, Konda Y, Marusawa H, Kanai M, Nakajima T, Kawashima T, Nanakin A, Sawabu T, Uenoyama Y, et al: STAT3 is constitutively activated and supports cell survival in association with survivin expression in gastric cancer cells. Oncogene 23: 4921-4929, 2004.

29. Yang MD, Lai KC, Lai TY, Hsu SC, Kuo CL, Yu CS, Lin ML, Yang JS, Kuo HM, Wu SH, et al: Phenethyl isothiocyanate inhibits migration and invasion of human gastric cancer AGS cells through suppressing MAPK and NF-kappaB signal pathways. Anticancer Res 30: 2135-2143, 2010.

30. Yakata Y, Nakayama T, Yoshizaki A, Kusaba T, Inoue K and Sekine I: Expression of p-STAT3 in human gastric carcinoma: Significant correlation in tumour invasion and prognosis. Int $\mathrm{J}$ Oncol 30: 437-442, 2007.

31. Duan H, Qu L and Shou C: Activation of EGFR-PI3K-AKT signaling is required for Mycoplasma hyorhinis-promoted gastric cancer cell migration. Cancer Cell Int 14: 135, 2014.

32. Velázquez E, Santos A, Montes A, Blázquez E and RuizAlbusac JM: 25-Hydroxycholesterol has a dual effect on the proliferation of cultured rat astrocytes. Neuropharmacology 51: 229-237, 2006.

33. Travert C, Carreau S and Le Goff D: Induction of apoptosis by 25-hydroxycholesterol in adult rat Leydig cells: Protective effect of 17beta-estradiol. Reprod Toxicol 22: 564-570, 2006.

34. Choi YK, Kim YS, Choi IY, Kim SW and Kim WK: 25-hydroxycholesterol induces mitochondria-dependent apoptosis via activation of glycogen synthase kinase-3beta in PC12 cells. Free Radic Res 42: 544-553, 2008

35. Yang L and Sinensky MS: 25-Hydroxycholesterol activates a cytochrome c release-mediated caspase cascade. Biochem Biophys Res Commun 278: 557-563, 2000.

36. Hoesel B and Schmid JA: The complexity of NF- $\mathrm{kB}$ signaling in inflammation and cancer. Mol Cancer 12: 86, 2013.

37. DiDonato JA, Mercurio F and Karin M: NF- $\kappa B$ and the link between inflammation and cancer. Immunol Rev 246: 379-400, 2012.

38. Gold ES, Diercks AH, Podolsky I, Podyminogin RL, Askovich PS, Treuting PM and Aderem A: 25-Hydroxycholesterol acts as an amplifier of inflammatory signaling. Proc Natl Acad Sci USA 111: 10666-10671, 2014. 
39. Koarai A, Yanagisawa S, Sugiura H, Ichikawa T, Kikuchi T, Furukawa K, Akamatsu K, Hirano T, Nakanishi M, Matsunaga K, et al: 25-Hydroxycholesterol enhances cytokine release and Toll-like receptor 3 response in airway epithelial cells. Respir Res 13: 63, 2012.

40. Kang MJ, Ryu BK, Lee MG, Han J, Lee JH, Ha TK, Byun DS, Chae KS, Lee BH, Chun HS, et al: NF-kappaB activates transcription of the RNA-binding factor HuR, via PI3K-AKT signaling, to promote gastric tumorigenesis. Gastroenterology 135: 2030-2042, 2042.e1-3, 2008.

41. Reboldi A, Dang EV, McDonald JG, Liang G, Russell DW and Cyster JG: Inflammation. 25-Hydroxycholesterol suppresses interleukin-1-driven inflammation downstream of type I interferon. Science 345: 679-684, 2014.

42. Tricarico PM, Gratton R, Braga L, Celsi F and Crovella S: 25-Hydroxycholesterol andinflammation in Lovastatin-deregulated mevalonate pathway. Int J Biochem Cell Biol 92: 26-33, 2017.

43. de Weille J, Fabre C and Bakalara N: Oxysterols in cancer cell proliferation and death. Biochem Pharmacol 86: 154-160, 2013.

44. Hyun JW, Holl V, Weltin D, Dufour P, Luu B and Bischoff P: Effects of combinations of 7beta-hydroxycholesterol and anticancer drugs or ionizing radiation on the proliferation of cultured tumor cells. Anticancer Res 22: 943-948, 2002.

45. Erridge C, Webb DJ and Spickett CM: 25-Hydroxycholesterol, 7beta-hydroxycholesterol and 7-ketocholesterol upregulate interleukin-8 expression independently of Toll-like receptor 1,2,4 or 6 signalling in human macrophages. Free Radic Res 41: 260-266, 2007.
46. Bauman DR, Bitmansour AD, McDonald JG, Thompson BM, Liang G and Russell DW: 25-Hydroxycholesterol secreted by macrophages in response to Toll-like receptor activation suppresses immunoglobulin A production. Proc Natl Acad Sci USA 106: 16764-16769, 2009.

47. Zhang Y, Li Y, Li Y, Li R, Ma Y, Wang H and Wang Y: Chloroquine inhibits MGC803 gastric cancer cell migration via the Toll-like receptor 9/nuclear factor kappa B signaling pathway. Mol Med Rep 11: 1366-1371, 2015.

48. Yue Y, Zhou T, Gao Y, Zhang Z, Li L, Liu L, Shi W, Su L and Cheng B: High mobility group box 1/toll-like receptor 4/myeloid differentiation factor 88 signaling promotes progression of gastric cancer. Tumour Biol: Mar 28, 2017 (Epub ahead of print). doi: $10.1177 / 1010428317694312$.

49. Fernandez-Garcia B, Eiró N, González-Reyes S, González L, Aguirre A, González LO, Del Casar JM, García-Muñiz JL and Vizoso FJ: Clinical significance of toll-like receptor 3, 4, and 9 in gastric cancer. J Immunother 37: 77-83, 2014.

50. West AC, Tang K, Tye H, Yu L, Deng N, Najdovska M, Lin SJ, Balic JJ, Okochi-Takada E, McGuirk P, et al: Identification of a TLR2-regulated gene signature associated with tumor cell growth in gastric cancer. Oncogene 36: 5134-5144, 2017. International (CC BY-NC-ND 4.0) License. 